\title{
Legitimointistrategioiden käyttö kuntien ympäristöraportoinnissa
}

\author{
Tanja Nybom, Aila Virtanen \& Marko Järvenpää
}

\begin{abstract}
Legitimation strategies in the environmental reports of Finnish towns
\end{abstract}

This paper focuses on the legitimation strategies used in the environmental reports of the five biggest towns in Finland. The data consist of environmental reports published by Helsinki, Tampere, Espoo, Vantaa and Oulu. The results of the content analysis show that the towns use strategies whose purpose is to modify the public's perception of the organization in a positive direction. The purpose of this study is to increase critical knowledge of the legitimation strategies in environment reports.

Keywords: legitimation theories, environmental reports, Finnish towns

\section{JOHDANTO}

\section{Tutkimuksen taustaa}

Ympäristölaskentatoimesta on tullut merkittävä osa erilaisten organisaatioiden ympäristönhallintaa. Ympäristö, kestävän kehityksen edistäminen ja vastuullisuuskysymykset ovat nostaneet päätään yhä enemmän ja ympäristöinformaation julkinen raportointi on lisääntynyt (Bremser 2014; Kolk 1999). Organisaatioiden motivaatio ympäristöraportoimiseen voi johtua monesta eri seikasta. Raportointi voi olla keino ilmaista yrityksen tai organisaation sitoutuminen ympäristöasioihin tai yhteisen vastuun tunnustaminen ympäristön tilasta. Raportoinnilla saatetaan pyrkiä erottautumaan kilpailijoista, osoittamaan rapotointiin liittyvien säädösten ja lakien noudattaminen tai hakemaan hyväksyntää organisaation toimille ympäristön suhteen (Azzone, Brophy, Noci, Welford \& Young 1997, 699). Sidosryhmien odotusten aiheuttama paine sekä raportointiin liittyvien standardien yleistyminen toimivat vahvana motivaationa raportoinnin kehittämiseen. Vastatakseen sidosryhmien odotuksiin ja vaatimuksiin organisaatio voi pyrkiä legitimoimaan eli todistamaan menettelytapojensa oikeellisuuden ja perustelemaan toimintansa jatkuvuuden sidosryhmiensä silmissä (Bennett, James \& Klinkers 1999, 385). Legitimointi ja ympäristöraportointi ovat tutkimusaiheena mielekäs aiheen tutkittavuuden ja yhteiskunnallisen merkityksen vuoksi. Raportointia ja ympäristölaskentatoimea on tutkittu paljon ja kehitetty eteenpäin jo 1990-luvulla, mutta aihe on edelleen ajankohtainen ja sen merkitys kasvaa edelleen tulevaisuudessa, kun yrityksiltä ja muilta organisaatioilta vaaditaan yhä enemmän ympäristöasioiden hallinnan suhteen (Adams, Hill, Roberts 1998; Gray, Owen \& Adams 1996; Niskala \& Pretes 1995). Kasvavat paineet organisaatioiden ympäristönhallintaa kohtaan oletettavasti kasvattavat tarvetta hakea toimintatavoille oikeutusta legitimoinnin keinoin.

Ympäristöraportointia tarkastellaan usein legitimoinnin näkökulmasta ja legitimaatioteoria on aikaisemmassa tutkimuksessa liitetty ympäristölaskentatoimen käsitteeseen (Freedman \& Jaggi 2010; Hrasky 2012; O’Dwyer, Owen \& Unerman 2011). Legitimointia ei ole juurikaan tutkittu kuntasektorin näkökulmasta, vaikka kuntien ympäristöraporteilla ja niissä käytetyillä legitimointistrategioilla on huomattava yhteiskunnallinen merkitys. Tämän tutkimuksen tarkoituksena on selvittää, millaisia legitimointistrategioita kunnat käyttävät ympäristöraporteissaan. Tarkoituksena on lisätä ymmärrystä siitä, miten ympäristöraportteihin tulisi suhtautua, ja miten niitä tulisi lukea ja tulkita. Työn teoreettinen viitekehys rakentuu sidosryhmäteorian näkökulmasta, ja aineiston analysointiin käytetään semanttisia ja visuaalisia legitimaatioteorioita. Legitimaatioteorioiden 
käyttö kuntien ympäristövastuun tarkasteluun muodostaa työn käsitteellisen kontribuution. Ympäristöraportointiin liittyy myös eettinen ulottuvuus (Adams 2004), joka rajataan tarkastelun ulkopuolelle.

\section{Kuntien ympäristöraportointi}

Aiemmassa tutkimuksessa ympäristöraportointia ja legitimointia on käsitelty lähinnä yritysten kannalta (Kolk 1999; Niskala \& Pretes 1995; Guenther, Hoppe \& Poser 2007; Hahn \& Lülfs 2014). Kuntien ja yritysten ympäristöraportoinnissa pätevät oletettavasti samat motivaatiotekijät. Molempien osalta sidosryhmät aiheuttavat yhtä lailla painetta sekä julkisella että yksityisellä sektorilla. Legitimoinnin näkökulmasta suurin ero on se, että kun yritykset käyttävät legitimointia oikeuttaakseen toimintansa jatkuvuuden, niin kuntien toiminta ei käytännössä voi lakata, vaikka ne menettäisivätkin sidosryhmiensä luottamuksen. Kunnilla ei myöskään ole samalla tavalla kilpailijoita kuin yrityksillä. Toisaalta kuntiin saattaa kohdistua jopa suurempi paine kuin yrityksiin, sillä julkisen organisaation toiminnan vaikutukset yhteiskunnan kehitykseen ovat yleensä yksittäisten yritysten aiheuttamia vaikutuksia suuremmat (Jussila 2010, 12; Kalpala 2004). Sen lisäksi, että kunnat joutuvat osoittamaan oman vastuullisuutensa, ne toimivat valvovana tahona muiden toimijoiden vastuullisuutta kohtaan. Tämän erityisaseman vuoksi kunnat määrittävät osaltaan sen mikä on vastuullista ja legitiimiä toimintaa (Anttiroiko 2004, 45).

Aiemmissa tutkimuksissa on havaittu, että organisaation koko ja toimialan herkkyys vaikuttavat ympäristöraportoinnin laajuuteen (Patten 2012). Mitä suuremmasta organisaatiosta tai ympäristöä kuormittavammasta toimialasta on kyse, sitä kattavampaa on myös raportointi. Suuri koko ja arvostelulle herkkä toimiala kasvattavat myös legitimoinnin tarvetta. Kuntaorganisaatioiden voidaan ajatella olevan melko suuria, joten on mahdollista, että legitimointikeinoja käytetään paljon. Kunnat eivät kuitenkaan suoraan toimi luonnonvaroja käyttävällä tai ympäristöä kuormittavalla alalla, joten toimialan puolesta voisi ajatella legitimoinnin olevan vähäistä (Kolk 1999; Niskala \& Pretes 1995; Guenther ym. 2007; Hahn \& Lülfs 2014).
Tässä tutkimuksessa keskitytään Suomen suurimpiin kuntiin, jotka ovat pyrkineet yhtenäistämään kestävän kehityksen toimintojensa mittaamista ja parantamaan näin ympäristöraporttiensa vertailukelpoisuutta. Suomen suurimmat kaupungit, eli niin kutsutut kuutoskaupungit, ovat tehneet yhdessä kaksi julkaisua koskien ympäristöasioiden vertailukelpoista mittaamista. Kuutoskaupunkeihin kuuluvat Espoo, Helsinki, Oulu, Tampere, Turku ja Vantaa. Ensimmäinen julkaisu, Kuutoskaupunkien kestävän kehityksen indikaattorit 2004-2006 (2008), julkaistiin vuonna 2008 jonka jälkeen vuonna 2012 julkaistiin indikaattorien toinen yhteenveto, Kuutoskaupunkien ekologisen kestävyyden indikaattorit 2006-2010 (2012). Kuutoskaupungit alkoivat seurata yhteisesti määriteltyjä kestävän kehityksen indikaattoreita vuonna 2004, jonka jälkeen yhteistyötä ympäristöasioiden mittaamisen kehittämiseksi on jatkettu. Yhteisillä indikaattoreilla pyritään parantamaan kuntien välistä vertailukelpoisuutta, mutta ongelmia tavoitteen toteutumiseen ovat aiheuttaneet esimerkiksi kuntaliitokset, ylikunnalliset toiminnot sekä palvelurakenteiden muutokset. Nämä vaikeuttavat indikaattoritietojen laskemista ja kuntien välistä vertailua (Kuutoskaupunkien ekologisen kestävyyden indikaattorit 2006-2010, 2012, 3).

Kuntien ympäristönsuojelun hallintoa koskevassa laissa (24.7.1986/64) säädetään kunnan ympäristösuojeluviranomaisesta ja viranomaisen ympäristönsuojelua koskevista tehtävistä. Tehtäviin kuuluu muun muassa ympäristönsuojelun suunnittelu ja kehittäminen, ympäristön tilan seuranta sekä ympäristönsuojelua koskeva tiedottaminen ja valistus (5.12.1996/1013). Kyseisten tehtävien voidaan ajatella liittyvän ympäristöraportointiin, sillä erilaiset ympäristöraportit toimivat tiedottamiskanavina ja voivat auttaa organisaatiota ympäristön tilan seurannassa ja toiminnan kehittämisessä. Ympäristöraportointi on siis huomionarvoinen aihe kuntaorganisaatioille, mutta kuntien ympäristöraportointia koskevaa ohjeistusta on julkaistu melko vähän. Konsulttiyhtiö Efeko Oy on julkaissut kunnan ympäristötilinpäätöksen laatimista koskevan ohjeen, joka käsittelee kunnan ympäristöasioiden laskentaa, kirjaamista ja raportointia lakisääteisen tilinpäätösinformaation sekä yhteiskuntavastuuta käsittelevien raporttien osana (Knuutila 2007, 6-7). Lisäksi työ- ja elinkeino- 
ministeriön kirjanpitolautakunnan (KILA) kuntajaosto on laatinut yleisohjeen ympäristöasioiden kirjaamisesta ja esittämisestä kunnan ja kuntayhtymän tilinpäätöksessä (Suomen Kuntaliitto, 2009). Kuten Efeko Oy:n ohjekin, myös KILA:n yleisohje opastaa ympäristöasioiden kirjaamista osana lakisääteistä tilinpäätösinformaatiota. Ohjeet koskevat vain lakisääteisen ympäristöinformaation esittämistä. Ohjeistusta vapaaehtoiseen, lakisääteistä laajempaan, ympäristöraportointiin ei siis kuntasektorin näkökulmasta ole tehty.

\section{LEGITIMAATIO}

\section{Sidosryhmäteoria}

Ympäristölaskentatoimeen läheisesti liittyvä teoria keskittyy sidosryhmiin, jotka vaikuttavat organisaation toimintaan ja joille organisaatio on vastuussa toimintansa vaikutuksista (Mätäsaho \& Niskala 1997; Azzone ym. 1997). Ympäristölaskentatoimi on sidosryhmäteorian mukaan eräänlaista kommunikaatiota organisaation ja sen sidosryhmien välillä. Organisaation menestys on riippuvaista sidosryhmien toiminnasta, joten sen on pyrittävä vastaamaan sidosryhmien odotuksiin mahdollisimman hyvin. Ympäristövastuu voidaankin nähdä vastuuna sidosryhmille. Jokainen sidosryhmä antaa omalla tavallaan panoksensa organisaatiolle, joten niillä nähdään olevan myös oikeus luoda odotuksia organisaation ympäristövastuun suhteen. Sidosryhmien intressit vaikuttavat siis merkittävästi organisaation ympäristöraportoinnin sisältöön (Amran \& Ooi 2014; Mätäsaho \& Niskala 1996, 297-298; Mätäsaho \& Niskala 1997, 8182).

Eri sidosryhmät asettavat eri odotuksia organisaation ympäristönhallinnasta saamalleen informaatiolle (Mätäsaho \& Niskala 1997, 82). Raportoidessaan ympäristöasioistaan organisaation tulee määritellä itselleen tärkeimmät sidosryhmät ja miettiä kenelle raportit suunnataan. Riippuen kohderyhmästä organisaatio voi Azzonen ym. (1997) mukaan joko raportoida melko yleisluontoisesti ympäristönhallintaan liittyvistä asioista tai vaihtoehtoisesti kiinnittää erityistä huomiota tiettyjä sidosryhmiä kiinnostaviin aspekteihin. Sidosryhmiltä tuleva paine ajaa organisaatioita todistamaan tehokkuutensa, vastuullisuutensa ja läpinäkyvyytensä ympäristöraportoinnin keinoin. Tämä auttaa organisaatioita säilyttämään imagoarvonsa ja toimintansa legitimiteetin. Kaikkien sidosryhmien odotuksiin ja vaatimuksiin vastaaminen on kuitenkin haastava tehtävä monelle toimijalle. Kuntasektorilla yksi tärkeimmistä sidosryhmistä on alueen asukkaat, jotka käyttävät kunnan palveluita.

\section{Legitimaatioteoria}

Legitimaatioteorian mukaan organisaatioiden tarkoitus on yhtenäistää toimintaansa liittyvä arvojärjestelmä sopivaksi laajemmassa yhteisössä vallitseviin hyväksyttyihin sosiaalisiin normeihin. Tällöin legitimaatiolla tarkoitetaan tilaa, jossa organisaation sosiaaliset arvot vastaavat ympäröivän yhteiskunnan arvojärjestelmää (Mätäsaho \& Niskala 1996, 298). Jos organisaation ympäristönhallintaan liittyvä toiminta ja tavoitteet eroavat niihin kohdistuvista sidosryhmien odotuksista, syntyy niin kutsuttu legitimaatioero tai legitimiteettikuilu. Organisaatio voi legitimoinnin keinoin pyrkiä kuromaan umpeen tätä eroa. Prosessia, jossa organisaatio pyrkii oikeuttamaan toimintansa jatkuvuuden tai todistamaan menettelynsä oikeellisuuden, kutsutaan legitimoinniksi (Mätäsaho \& Niskala 1996, 298; Mätäsaho \& Niskala, 1997, 84). Legitimaatioteorian mukaan organisaatiot reagoivat ympäristötekijöihin julkaisemalla tiedonantoja, joiden tarkoitus on legitimoida organisaation toimintatapoja. Teoria pohjautuu ajatukseen, jonka mukaan organisaatioiden ja yhteiskunnan välillä on sosiaalinen sopimus, jossa organisaatio sitoutuu toimimaan tietynlaisten sosiaalisten normien mukaan vastineeksi tavoitteidensa hyväksymisestä ja selviytymisensä mahdollistamisesta. Legitimoimalla toimintaansa julkaisujen keinoin, organisaatio pyrkii perustelemaan ja oikeuttamaan olemassaoloaan (Guthrie \& Parker 1989, 344).Freedman ja Jaggi (2010) esittävät, että organisaatiot voivat jatkaa olemassaoloaan vain, jos ympäröivä yhteiskunta mieltää organisaation toimintatavat yhteiskunnan arvojärjestelmän mukaisiksi eli jos toiminta mielletään legitiimiksi.

Organisaatiot voivat kohdata monia legitimaatiota uhkaavia tekijöitä, kuten vakavia ympäristöonnettomuuksia tai taloudellisia skan- 
daaleja. Vastatakseen uhkiin, organisaatiot saattavat pyrkiä palauttamaan legitimiteettinsä erilaisten laajojen legitimointistrategioiden kautta (Gregoriou \& Finch 2012, 3). Legitimaatioteorialla voidaan selittää esimerkiksi yleistä taipumusta korostaa ympäristöraportoinnissa organisaatiokäyttäytymisen positiivisia puolia negatiivisten aspektien sijaan (Freedman \& Jaggi 2010, 28). Organisaatiot voivat pyrkiä oikeuttamaan toimintansa julkaisemalla itselleen edullisia lausuntoja ympäristökysymyksistä. Negatiivisista asioista, kuten ympäristöonnettomuuksista ja niiden taloudellisista seurauksista, ei mielellään raportoida. Näin ollen raportit saattavat sisältää hyvinkin valikoivaa informaatiota (Mätäsaho \& Niskala 1997, 88).

Boydin (2000) mukaan suurin osa legitimaatioon liittyvästä teoriasta keskittyy institutionaaliseen legitimaatioon, jossa pyrkimyksenä on legitimoida organisaatiota kokonaisuutena ja sen olemassaolon jatkuvuutta. Institutionaalisen legitimaation tavoitteleminen liitetään usein kriisitilanteisiin, kuten ympäristöonnettomuuksiin, jotka voivat pahimmillaan vaarantaa toiminnan jatkuvuuden ja organisaation täytyy legitimoida toimintaansa laajasti. Toiminnallinen legitimaatio sen sijaan pyrkii legitimoimaan yksittäisiä toimia tai menettelytapoja. Toiminnallisen legitimaation tavoitteleminen ei liity niinkään kriisinhallintaan vaan se koskee vähemmän mullistavia ja yleisimmin esiintyviä aihepiirejä. Kriisinhallintaan liittyvä institutionaalinen näkökulma tarkastelee legitimaatiota jonkin tapahtuman jälkeen, kun taas toiminnallinen ulottuvuus keskittyy legitimaation saavuttamiseen ennen tekojen toimeenpanoa (Boyd 2000). Toiminnallinen legitimaatio on Boydin (2000) mukaan tärkeä tutkimusaihe, sillä on paljon organisaatioita, jotka eivät ikinä kohtaa laajoja legitimointitoimia vaativaa kriisitilannetta. Toiminnallisen legitimaation voidaan ajatella olevan kuntasektorin kannalta oleellisempi näkökulma, sillä kuntaorganisaation toiminta ei todennäköisesti johda suurten ympäristökatastrofien syntymiseen.

\section{Semanttiset legitimointistrategiat}

Legitimaatiota tutkivassa kirjallisuudessa on viitattu usein Lindblomin (1994) esittämiin neljään legitimointistrategiaan, joita yritykset voivat käyttää ympäristöraportoinnissaan (Michelon 2011; Mätäsaho \& Niskala 1996, 298299; Freedman \& Jaggi 2010, 28). Yritys voi ensinnäkin informoida tai valistaa sidosryhmiään toimenpiteidensä aiheuttamista muutoksista ympäristöön. Tämä strategia valitaan tyypillisesti silloin, jos yrityksen toiminta ei ole vastannut sidosryhmien odotuksia. Toiseksi yritys voi yrittää muuttaa sidosryhmien käsityksiä yrityksen ympäristönhallinnasta muuttamatta silti omia toimintatapojaan. Selittämällä toimintansa tarkoituksenmukaisuutta yritys voi yrittää korjata mielestään tapahtuneita väärinkäsityksiä. Kolmanneksi yritys saattaa pyrkiä manipuloimaan sidosryhmien käsityksiä tai ohjaamaan huomiota pois tietynlaisista ympäristökysymyksistä. Esimerkiksi ympäristöä merkittävästi toiminnallaan kuormittavat organisaatiot saattavat korostaa toimintansa positiivisia puolia jättämällä samalla toiminnan aiheuttamat negatiiviset vaikutukset joko pienelle huomiolle tai kokonaan raportoimatta. Neljäs Lindblomin (1994) esittämä strategia on pyrkiä muuttamaan sidosryhmien odotuksia koskien hyväksyttäviä toimintatapoja. Legitimaatiostrategioiden noudattamiseen raportoinnissa vaikuttavat eri ajankohdat ja ympäristökysymysten luonne.

Kunnat itsessään eivät toimi ympäristöä kuormittavalla alalla eivätkä yleensä joudu varsinaista kriisinhallintaa vaativiin tilanteisiin, joissa vaaditaan reaktiivisia legitimointikeinoja. Näin ollen, on syytä kiinnittää huomiota proaktiivisiin strategioihin, joiden käyttöön ei välttämättä liity kriisitilannetta. Hahn ja Lülfs (2014) kokoavat yhteen eri tutkijoiden määrittelemiä legitimaation säilyttämiseen liittyviä strategioita. Vaikka Hahn ja Lülfs kuvaavat erityisesti negatiivisten tapahtumien legitimointiin käytettyjä strategioita, niin monet näistä strategioista soveltuvat myös legitimaation kasvattamiseen yleisesti. Organisaatio voi käyttää raportoinnissaan esimerkiksi Merkl-Daviesin ja Brennanin (2007) peittelystrategiaa, jolloin negatiivista informaatiota monimutkaistetaan tarkoituksellisesti käyttämällä vaikeasti ymmärrettävää kieltä. Peittely voi ilmetä myös positiivisten asioiden korostamisena ja informaation esittämisenä mahdollisimman miellyttävässä muodossa. Attribuutiostrategian mukaan taas toiminnan positiiviset seuraukset liitetään organisaation sisäisiin tekijöihin, mutta negatiiviset seuraukset 
johtuvat organisaation ulkopuolisista tekijöistä (Merkl-Davies \& Brennan 2007). Näin toimien onnistumisista otetaan suurempi vastuu kuin epäonnistumisista.

Korjaavat toimenpiteet pitävät sisällään epätarkat lausunnot siitä, kuinka ongelmiin on puututtu tai aiotaan puuttua jatkossa tai kuinka ongelmat aiotaan välttää kokonaan. Ratkaisuja kuvaillaan epäselvillä ja ylimalkaisilla adjektiiveilla ilmauksilla (Hahn \& Lülfs, 2014). Lisäksi tähän strategiaan kuuluvat lausunnot, joissa luvataan korjata ongelmat tai vakuutetaan, että negatiivisiin asioihin tullaan puuttumaan (Benoit 1997).

Hahn ja Lülfs (2014) viittaavat Lindblomin (1994) kehittämiin legitimointistrategioihin, joita voidaan käyttää proaktiivisesti legitimoimaan yrityksen toimintaa. Ensimmäinen näistä strategioista on muutoksen kommunikointi, jolloin organisaatio muokkaa toimintaansa ja kommunikoi tehdyistä muutoksista raporteissaan. Toinen strategia on käsitysten muuttaminen. Tällöin organisaatio pyrkii osoittamaan toimintansa tarkoituksenmukaisuuden muuttamatta kuitenkaan toimintaansa. Organisaatio voi myös identifioitua symboleihin eli manipuloida sidosryhmien näkemyksiä yhdistämällä toimintansa suuren legitimiteetin omaaviin symboleihin. Neljännen strategian mukaan organisaatio voi pyrkiä muokkaamaan ulkopuolisia näkemyksiä ja odotuksia tiedottamisen ja valistamisen kautta. Edellä esitellyt legitimointistrategiat ovat Hahnin ja Lülfsin (2014) näkemys siitä, mitkä strategiat ovat luonteeltaan proaktiivisia. Ei kuitenkaan voida yksiselitteisesti määrittää mitä strategioita voidaan käyttää proaktiivisesti ja mitä reaktiivisesti.

\section{Visuaaliset legitimointistrategiat}

Näköaistin on todettu olevan ihmisen hallitsevin aisti (Cho, Michelon \& Patten 2012), joten erilaisten kuvien ja graafien käyttö on tehokas kommunikointikeino (Hrasky 2012; Cho, Michelon \& Patten 2012). Lukija kiinnittää ensimmäisenä huomionsa visuaalisiin asioihin ja keskittyy vasta sen jälkeen tekstiosioihin. Graafeja käytetään kommunikoinnin apuna usein myös selventämään numeerisesta aineistosta saatuja tietoja ja graafiset kuviot jäävät taulukoitua tai kuvailevaa tietoa helpommin mieleen
(Hrasky 2012). Visuaalisen kommunikoinnin tehokkuuden vuoksi yritykset käyttävät sekä valokuvia että graafeja raportoinnissaan hallitakseen ja luodakseen mielikuvia ja käsityksiä yrityksestä itsestään tai raportoimistaan teemoista. Visuaalisten keinojen käyttöä voidaan mahdollisesti selittää legitimaatioteorian avulla (Hrasky 2012; Cho, Michelon \& Patten 2012). Legitimaatioteorian mukaan organisaatiot pyrkivät usein esittämään itsensä positiivisessa valossa. Tällaista menettelyä voidaan havaita myös käytettäessä visuaalisia raportointikeinoja. Cho, Michelon ja Patten (2012) esittävät, että suuri osa yritysten käyttämistä graafeista kuvaa positiivista kehitystä tai jos graafissa on vääristymiä, kuten poikkeavan skaalan käyttö, tarkoitus on aiheuttaa todellisuutta positiivisempi mielikuva graafin kuvaamasta asiasta. Yritys voi siis pyrkiä esittämään toimintansa positiivisessa valossa valitsemalla tarkoituksella raporttiinsa positiiviseen suoriutumiseen liittyviä graafeja.

Kim, Bach ja Clelland (2007) erottavat kaksi legitimointistrategioihin liittyvää lähestymistapaa (Hrasky 2012). Ensimmäinen näkemys on, että yritysten toiminnastaan levittämän tiedon tarkoitus on osoittaa toiminnan olevan vastuullisuuskäsitysten ja yhteiskunnan odotuksien mukaista. Tämä lähestymistapa liittyy moraaliseen legitimaatioon, jota yritys voi tavoitella vain, jos sen toiminta todella on vastuullista. Toisen näkemyksen mukaan legitimointipyrkimykset voivat pohjautua symboliseen lähestymistapaan, jolloin lausunnoilla yritetään luoda mielikuva vastuullisuudesta, vaikka tosiasiassa yrityksen toimet eivät vastaa annettua kuvausta. Symbolinen strategia liittyy pragmaattisen legitimaation tavoittelemiseen, jolloin väitteet vastuullisuudesta eivät pohjaudu tosiasiallisiin tekoihin vaan väitteiden ensisijainen tarkoitus on synnyttää positiivinen kuva yrityksen toiminnasta. Valokuvia ja graafeja voidaan käyttää molempien strategioiden tukena, mutta käytön laajuus riippuu pitkälti siitä kumpaa lähestymistapaa yritys noudattaa.

Jos valokuvat ovat luonteeltaan yleisluontoisia eikä niiden ja yrityksen toiminnan välillä ole havaittavissa suoraa yhteyttä, niin kuvien käytön voidaan ajatella olevan symbolista, jolloin tarkoitus on vaikuttaa lukijalle syntyviin mielikuviin yrityksestä. Tällaisia kuvia voivat olla 
esimerkiksi kuvat iloisista ihmisistä tai kauniista luonnonmaisemasta. Valokuvilla voidaankin tehokkaasti luoda mielikuva vastuullisesta yrityksestä ja samalla ohjata huomiota pois negatiivisista asioista. Moraaliseen legitimaatioon liittyvät kuvat taas ovat selvästi yhdistettävissä yrityksen toimiin ja ne kuvaavat yksityiskohtaisemmin ympäristönhallintaan ja vastuullisuuteen liittyviä asioita. Tämän strategian mukaiset teemat voivat liittyä esimerkiksi kierrätykseen tai uusiutuvan energian käyttöön. Kuvien tarkoitus on mielikuvien luomisen sijaan pikemminkin yrityksen todellisen toiminnan ja saavutusten korostaminen. Valokuvat ovat siis tehokas keino kiinnittää lukijan huomio yrityksen haluamiin asioihin, jolloin valokuvien käyttö voi tukea graafien käyttöä moraalista legitimaatiota tavoiteltaessa. Vastuullisten yritysten oletetaankin graafien lisäksi käyttävän jonkin verran valokuvia osana visuaalista raportointiaan (Hrasky 2012). Vaikka graafien ajatellaan kuvaavan kvantitatiivisen luonteensa vuoksi todellista toimintaa, voidaan niitä silti käyttää myös symbolisen strategian tukena. Symbolista strategiaa noudattavat yritykset voivat käyttää raporteissaan graafeja, jotka ovat esteettisesti miellyttäviä, mutta jotka eivät ilmennä kuvattavaa asiaa tarkimmalla mahdollisella tavalla. Cho, Michelon ja Patten (2012) esittävät, että yritykset voivat myös tuoda esille positiivisia saavutuksiaan graafeilla ja ohjata huomiota pois negatiivisista aspekteista. On mahdollista, että ainoastaan positiivinen kehitys kuvataan graafien avulla ja negatiivisesta kehityksestä saatetaan mainita vain tekstin seassa, jolloin positiivisille asioille asetetaan enemmän painoarvoa. Graafeja saatetaan myös muokata antamaan todellisuutta positiivisempi kuva vääristelemällä esimerkiksi graafin asteikkoja tai mittasuhteita. Näin positiivisia trendejä pystytään liioittelemaan ja negatiivisten trendien merkitystä vähättelemään. Pelkästään positiivista kehitystä kuvaavien graafien esittämisestä ei kuitenkaan voida yksiselitteisesti tehdä johtopäätöstä symbolisen strategian käytöstä ja vastuullisuuden noudattamatta jättämisestä. On myös mahdollista, että yritys todella on parantanut suoriutumistaan ja positiiviset tulokset ovat osoitus kehityksestä.

\section{Viitekehys aineiston analyysia varten}

Kuntien organisaatiorakenne, sidosryhmät ja toiminta poikkeavat suuresti muista organisaatioista. Kuntien ympäristöraporttien tarkasteluun käytettävää viitekehystä ei ennestään ole, vaan se rakennetaan teoriaan pohjautuen.

Kuntien ympäristöraportit ovat heikosta lainsäädännöstä johtuen erilaisia sisällöltään, rakenteeltaan ja tasoltaan. Ympäristöraporttien erilaisuudesta johtuen niiden laadun tarkastelu ilman viitekehystä tai määrällinen mittaaminen eivät sovellu empiirisen analyysin työkaluksi. Sidosryhmäteoriasta lähtien legitimointistrategiat tarjoavat analyysiin soveltuvan joustavan viitekehyksen, joka huomioi sekä kielellisen että visuaalisen vaikuttamisen keinot. Viitekehys ottaa huomioon ympäristöraportteihin sisältyvät erilaiset vaikuttamistavat monipuolisesti, ja sen käyttö sopii kuntien erilaisten ympäristöraporttien analyysiin. Viitekehys myös sallii subjektiivisen tulkinnan aineiston käsittelyssä, mutta antaa tulkinnalle tietyt rajat, joiden puitteissa analyysi voidaan laatia luotettavalla tavalla.

Seuraavassa taulukossa kuvataan sidosryhmäteoriaan perustuva, toiminnallisia ja proaktiivisia legitimointistrategioita hyödyntävä viitekehys, jota käytetään empiirisen osan analysoinnissa. Viitekehyksen muodostavat Lindblomin (1994) esittämät legitimointistrategiat, toiminnan muuttamisesta informointi, jo tapahtuneiden muutosten informointi ja suunniteltujen muutosten informointi. Mielikuvien muokkaamiseen liittyviä strategioita ovat symboleihin identifiointi, imagon kohentaminen ja korjaavat toimenpiteet (Mätäsaho \& Niskala, 1996, 298299; Freedman \& Jaggi, 2010, 28). Lisäksi analyysiin valitaan Merkl-Daviesin ja Brennanin (2007) peittelystrategia, koska peittelyn käyttäminen ympäristöraportoinnissa on kuntalaisille erityisen vaikeaa havaita. Graafisten legitimointistrategioiden esitys on jaettu positiivista kehitystä ja negatiivista kehitystä kuvaaviin graafeihin. 
Taulukko 1. Empiirisessä analyysissä käytettävä viitekehys

\begin{tabular}{|l|l|l|}
\hline Semanttiset strategiat & Toiminnan muuttaminen & Tapahtuneet muutokset \\
\hline & & Suunnitellut muutokset \\
\hline & Mielikuvien muokkaaminen & Symboleihin assosiointi \\
\hline & & Itsensä korostaminen \\
\hline & & Peittely \\
\hline & & Korjaavat toimenpiteet \\
\hline & & Näkemysten ja odotusten muuttaminen \\
\hline & Graafinen esitys & Positiivinen trendi \\
\hline & & Negatiivinen trendi \\
\hline & & Neutraali \\
\hline & Valokuvien käyttö & Toimintaa kuvaava \\
\hline & & Ei toimintaa kuvaava \\
\hline & &
\end{tabular}

\section{TUTKIMUSKYSYMYS, AINEISTO JA TUTKIMUSMENETELMÄ}

\section{Tutkimuksen tavoite, tutkimuskysymys ja aineisto}

Tutkimuksen tavoitteena on selvittää, minkälaisia legitimaatiostrategioita Suomen suurimpien kuntien ympäristönhallintaan liittyvissä raporteissa esiintyy. Tutkimuksessa keskitytään kartoittamaan kuntien käyttämiä legitimaation ylläpitämiseen tai laajentamiseen tarkoitettuja proaktiivisia strategioita, jotka eivät liity kriisitilanteisiin. Empiirisen tarkastelun teoreettinen viitekehys on esitetty Taulukossa 1.

Tutkimuksen tavoitteiden ja teoreettisen viitekehityksen pohjalta tutkimuskysymys muodostuu seuraavanlaiseksi; Minkälaisia semanttisia ja visuaalisia legitimointistrategioita Suomen suurimmat kunnat käyttävät ympäristöraportoinnissaan? Tutkimus on kvalitatiivinen tutkimus ja aineiston analysointimenetelmä on laadullinen sisällönanalyysi, joka toteutetaan teorialähtöisesti. Aineistona käytetään Suomen suurimpien kaupunkien ympäristöraportointiin ja kestävän kehityksen raportointiin liittyviä julkaisuja. Julkaisuihin kuuluu kaupunkien ympäristöraportteja, ympäristötilinpäätöksiä ja kestävän kehityksen seurantaraportteja. Suomen asukasluvultaan suurimmat kaupungit olivat vuoden 2014 lopussa: Helsinki, Espoo, Tampere, Vantaa, Oulu ja Turku (Väestörekisterikeskus
2014). Tutkimuksen aineistoon on otettu mukaan viiden suurimman kaupungin ympäristönhallintaan liittyviä raportteja, sillä Turun kaupungin osalta ei ole saatavilla tarpeeksi raportteja tarkasteluajankohdalta.

Aineistovalinnan perusteena olivat raporttien hyvä saatavuus, kaupunkien kattava raportointi ympäristöön liittyen sekä kaupunkien vertailukelpoisuus. Raporttien vertailukelpoisuutta parantaa se, että nämä kaupungit ovat tehneet yhteistyötä kestävän kehityksen raportoinnin yhtenäistämiseksi ja kehittäneet aiheeseen liittyviä indikaattoreita. Lisäksi, näkyvyyden ja paineiden vuoksi voidaan olettaa, että suurilla kunnilla on myös suurempi tarve käyttää legitimointistrategioita raportoinnissaan. Taulukossa 2 esitetään kuutoskaupunkien julkaisemat ympäristöraportit vuosittain. Jotta aineisto olisi mahdollisimman yhtenäinen ja vertailukelpoinen, on tutkimuksen kannalta olennaista valita tarkasteluun samaan aikaan julkaistuja raportteja jokaiselta kaupungilta.

Tarkasteluun on valittu mahdollisimman kattavan aineiston saamiseksi seuraavat ympäristöraportit: Helsinki: 2006, 2008, 2010, 2013; Espoo: 2006, 2008, 2010, 2013; Tampere: 2006, 2008, 2010, 2013; Vantaa: 2008, 2010, 2013; Oulu: 2006, 2008, 2010, 2013. Vantaan kaupungilta ei löydy raporttia vuodelta 2006, mutta muilta vuosilta raportteja löytyy sen verran, että Vantaata voidaan verrata muihin kaupunkeihin. 
Taulukko 2. Kuutoskaupunkien julkaisemat ympäristöraportit vuosittain

\begin{tabular}{|l|c|c|c|c|c|c|c|c|c|c|c|c|c|}
\hline & 2001 & 2002 & 2003 & 2004 & 2005 & 2006 & 2007 & 2008 & 2009 & 2010 & 2011 & 2012 & 2013 \\
\hline Helsinki & $\mathrm{x}$ & $\mathrm{x}$ & $\mathrm{x}$ & $\mathrm{x}$ & $\mathrm{x}$ & $\mathrm{x}$ & $\mathrm{x}$ & $\mathrm{x}$ & $\mathrm{x}$ & $\mathrm{x}$ & $\mathrm{x}$ & $\mathrm{x}$ & $\mathrm{x}$ \\
\hline Espoo & & & & $\mathrm{x}$ & & $\mathrm{x}$ & & $\mathrm{x}$ & & $\mathrm{x}$ & & $\mathrm{x}$ \\
\hline Tampere & & & & & & $\mathrm{x}$ & & $\mathrm{x}$ & & $\mathrm{x}$ & $\mathrm{x}$ & $\mathrm{x}$ & $\mathrm{x}$ \\
\hline Vantaa & & & & & & & $\mathrm{x}$ & $\mathrm{x}$ & $\mathrm{x}$ & $\mathrm{x}$ & $\mathrm{x}$ & $\mathrm{x}$ & $\mathrm{x}$ \\
\hline Oulu & & & & $\mathrm{x}$ & $\mathrm{x}$ & $\mathrm{x}$ & $\mathrm{x}$ & $\mathrm{x}$ & $\mathrm{x}$ & $\mathrm{x}$ & $\mathrm{x}$ & $\mathrm{x}$ & $\mathrm{x}$ \\
\hline Turku & $\mathrm{x}$ & $\mathrm{x}$ & $\mathrm{x}$ & $\mathrm{x}$ & $\mathrm{x}$ & $\mathrm{x}$ & $\mathrm{x}$ & $\mathrm{x}$ & & & & & \\
\hline
\end{tabular}

Tutkimus keskittyy siis Suomen viiden suurimman kaupungin ympäristöraportointikäytäntöihin aikavälillä 2006-2013.

\section{Laadullinen sisällönanalyysi}

Aineiston analysointimenetelmäksi on valittu laadullinen sisällönanalyysi. Laadullisen sisällönanalyysin avulla voidaan systemaattisesti kuvata aineiston merkitystä tietystä näkökulmasta, jonka tutkimuskysymykset määrittävät (Schreier 2012, 3-4).

Analyysi toteutetaan deduktiivisesti eli teorialähtöisesti (Tuomi \& Sarajärvi 2009, 113; Schreier 2012, 60). Sisällönanalyysin tukena käytetään taulukon 1 mukaista viitekehystä. Viitekehys on strukturoitu eli aineistosta kerätään ainoastaan viitekehykseen sopivia asioita (Tuomi \& Sarajärvi 2009, 113). Aineistosta pyritään tunnistamaan ilmauksia, jotka vastaavat merkitykseltään semanttisten strategioiden alakategorioita ja joilla pyritään osoittamaan toiminnassa tehdyt muutokset tai muokkaamaan sidosryhmien mielikuvia. Visuaalisia strategioita tutkimalla pyritään selvittämään, käytetäänkö graafeja ja valokuvia raporteissa legitimointitarkoitukseen.

Aineistosta etsitään systemaattisesti jokaista Taulukossa 1 esiintyvää strategiaa kuvaavia lauseita ja ilmauksia sekä valokuvia. Kun jokaista strategiaa ilmentävät lauseet ja valokuvat on tunnistettu, lasketaan niiden määrä yhteen.

Toiminnan muuttamista koskevaa strategiaa tarkasteltaessa huomioidaan lausunnot organisaation aktiivisista toimista, mutta ei passiivissa esitettyjä esimerkkejä siitä, kuinka jokin asia on muuttunut. Jos organisaatio kuvailee passiivia käyttäen esimerkiksi päästöjen laskeneen $\mathrm{x} \%$, ei muutoksella katsota olevan yhteyttä organisaa- tion tekemiin toimiin päästöjen vähentämiseksi. Suunniteltuja muutoksia kuvaavia lausuntoja tarkasteltaessa huomioidaan organisaation raportissaan kuvaamat konkreettiset tavoitteet tulevaisuudelle. Taloudellisen informaation osioissa lueteltuja ympäristöinvestointeja ei lasketa osaksi itsensä korostamista, sen sijaan muualla raportissa selvästi korostetut rahalliset panostukset lasketaan osaksi kyseistä strategiaa. Symboleihin identifiointia tarkastellaan laskemalla viittauksia lakeihin, määräyksiin ja standardeihin, legitiimeihin auktoriteetteihin tai benchmarkeihin sekä yhteistyöhön eri toimijoiden kanssa. Lisäksi lasketaan epätarkkoja ja yleisluontoisia eettisiä lausuntoja, jotka koskevat yleistä huolta ympäristöstä, vastuullisuutta ja sidosryhmien huomioonottamista.

Graafien kuvaaman asian kehityssuunta tulkitaan vertaamalla edellisvuoteen. Ilmiöiden kehityksessä voi esiintyä vaihtelua vuosittain, jolloin graafeista voi olla hankalaa tulkita onko kehitys positiivista vai negatiivista. Edellisvuoteen vertaaminen helpottaa tulkitsemista. Tämä saattaa vääristää tuloksia, jos jotkut graafit tulkitaan positiivisiksi, vaikka yleinen trendi olisi ollut negatiivinen.

Valokuvia tarkasteltaessa erotetaan toisistaan toimintaa heijastavat valokuvat ja valokuvat, joilla ei ole suoraa kytköstä organisaation toimintaan. Valokuvat jaotellaan näin, koska valokuvien määrä itsessään ei kerro onko kyseessä symbolinen legitimointistrategia vai keino ohjata huomiota tärkeisiin asioihin. Kuvien määrien suhde kertoo Hraskyn (2012) mukaan, käytetäänkö valokuvia ensisijaisesti keinona kiinnittää lukijan huomio todenmukaisiin saavutuksiin vai vastuullisen mielikuvan luomiseen, joka ei välttämättä perustu todellisuuteen. 
Toimintaa heijastaviin valokuviin lasketaan kuvat, jotka ilmentävät konkreettisia toimenpiteitä tai joilla on selkeä yhteys tekstissä raportoituihin asioihin. Haastateltujen henkilöiden tai avainasemassa olevien henkilöiden kuvat lasketaan toimintaa ilmentäviin kuviin. Tällainen voi olla esimerkiksi kaupunginjohtajan kuva, joka on yhdistetty kaupunginjohtajan kirjoittamaan katsaukseen raportin teemoista.

Valokuviin, jotka eivät ilmennä organisaation toimintaa, lasketaan kuvat maisemista tai iloisista ihmisistä. Kyseiset valokuvat eivät kuvaa organisaation konkreettisia toimia eikä niillä ole suoraa liityntäkohtaa raportoituihin asioihin. Valokuvat, joilla ei tulkita olevan suoraa yhteyttä organisaation toimintaan voivat kuitenkin myös ilmentää konkreettisia toimia. Kuvissa voi olla esimerkiksi rakennustyömiehiä töissään, mutta jos kuvalla ei ole selvää liityntäkohtaa tekstissä mainittuihin asioihin, kuva lasketaan toimintaan liittymättömäksi. Valokuvia laskettaessa ei huomioida karttakuvia tai piirrettyjä kuvia.

Lisäksi tutkimuksessa tarkastellaan käyttävätkö kunnat suhteessa enemmän graafista esitystapaa vai valokuvia. Jos graafien käyttö on selvästi suositumpaa kuin valokuvien käyttö, voidaan tämän ajatella kertovan aidosti vastuullisesta toiminnasta, jota perustellaan konkreettisella informaatiolla. Jos taas valokuvia käytetään selvästi graafeja enemmän, on tämä mahdollisesti merkki pyrkimyksestä luoda mielikuva legitiimistä toiminnasta, joka ei välttämättä perustu todellisuuteen.

Eri kaupunkien legitimointistrategiat on koottu ensin taulukoihin, Määrät on suhteutettu raporttien sivumääriin eri vuosien, ja toisaalta myös kaupunkien välisen, vertailun helpottamiseksi. Taulukoissa on lueteltu erikseen toiminnan muuttamiseen ja mielikuvien muokkaamiseen liittyvien semanttisten strategioiden käyttö vuosittain. Lisäksi visuaalisiin strategioihin liittyen on taulukoitu erityyppisten graafien ja valokuvien käytön laajuus ja niiden suhde toisiinsa. Esityksen selkeyttämiseksi taulukkojen tiedot on kuvattu graafeina.

\section{TUTKIMUKSEN TULOKSET}

\section{Semanttiset strategiat}

Seuraavat graafit kuvaavat semanttisten strategioiden käyttöä kohdekuntien ympäristöraporteissa.

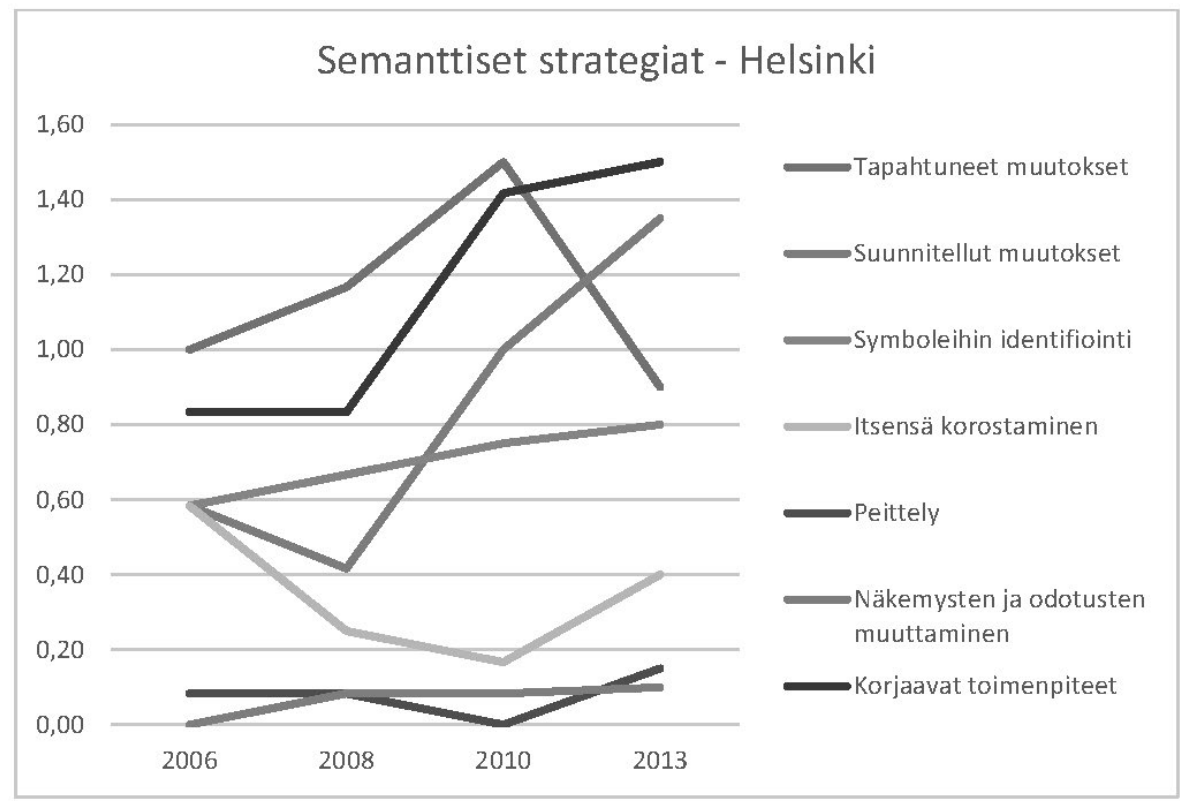

Kuvio 1. Semanttisten strategioiden käyttö - Helsinki 


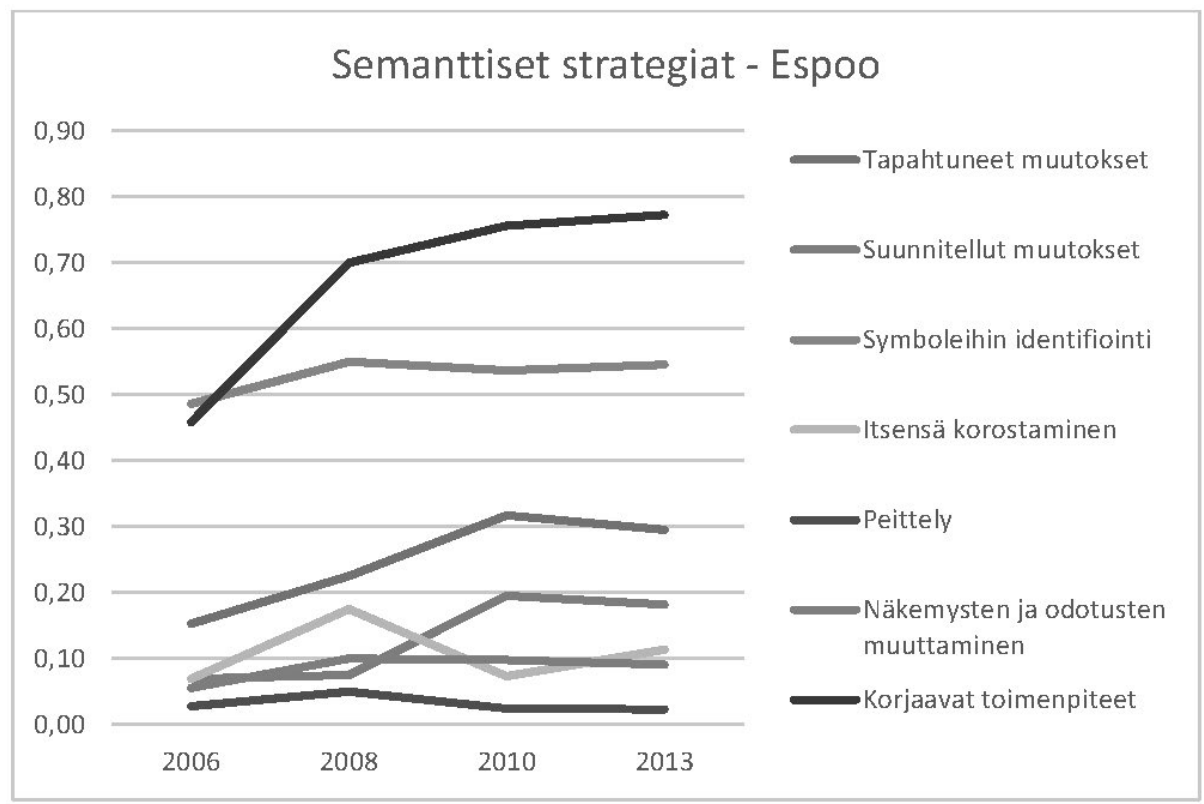

Kuvio 2. Semanttisten strategioiden käyttö - Espoo

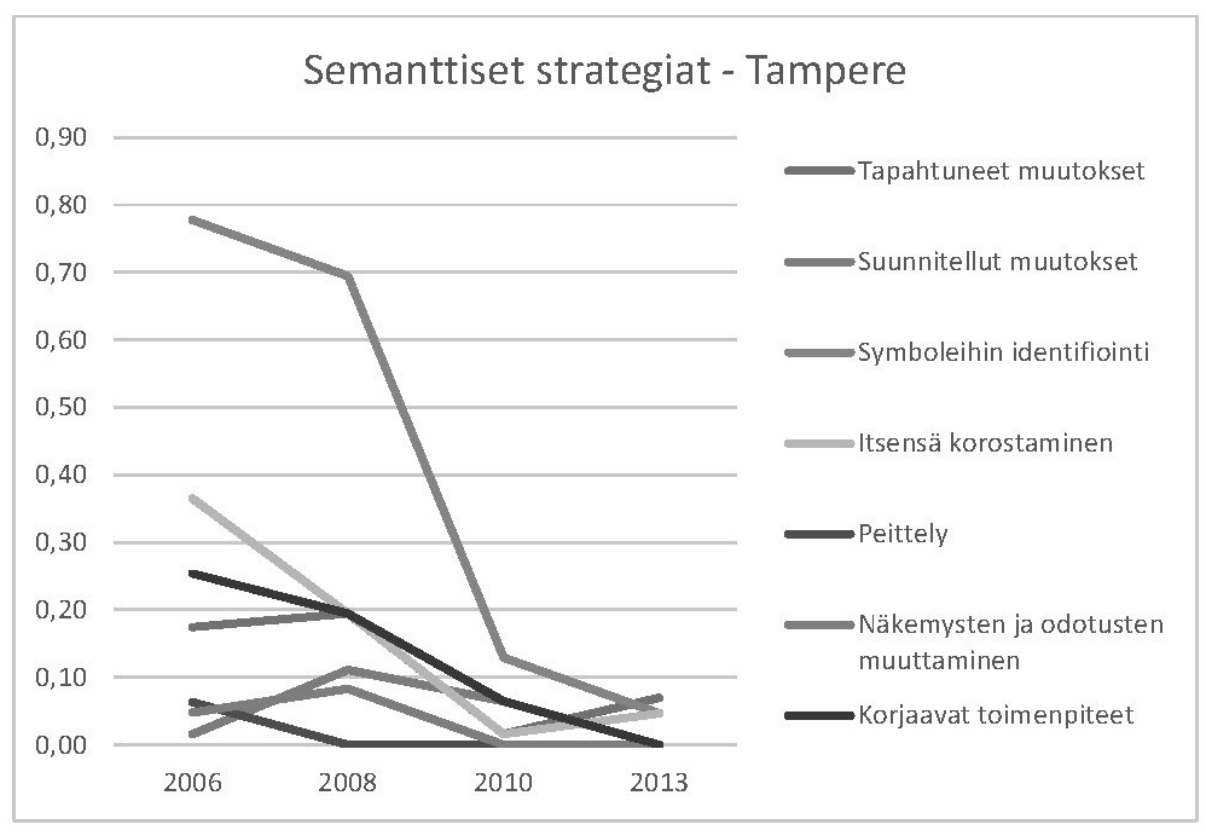

Kuvio 3. Semanttisten strategioiden käyttö - Tampere 


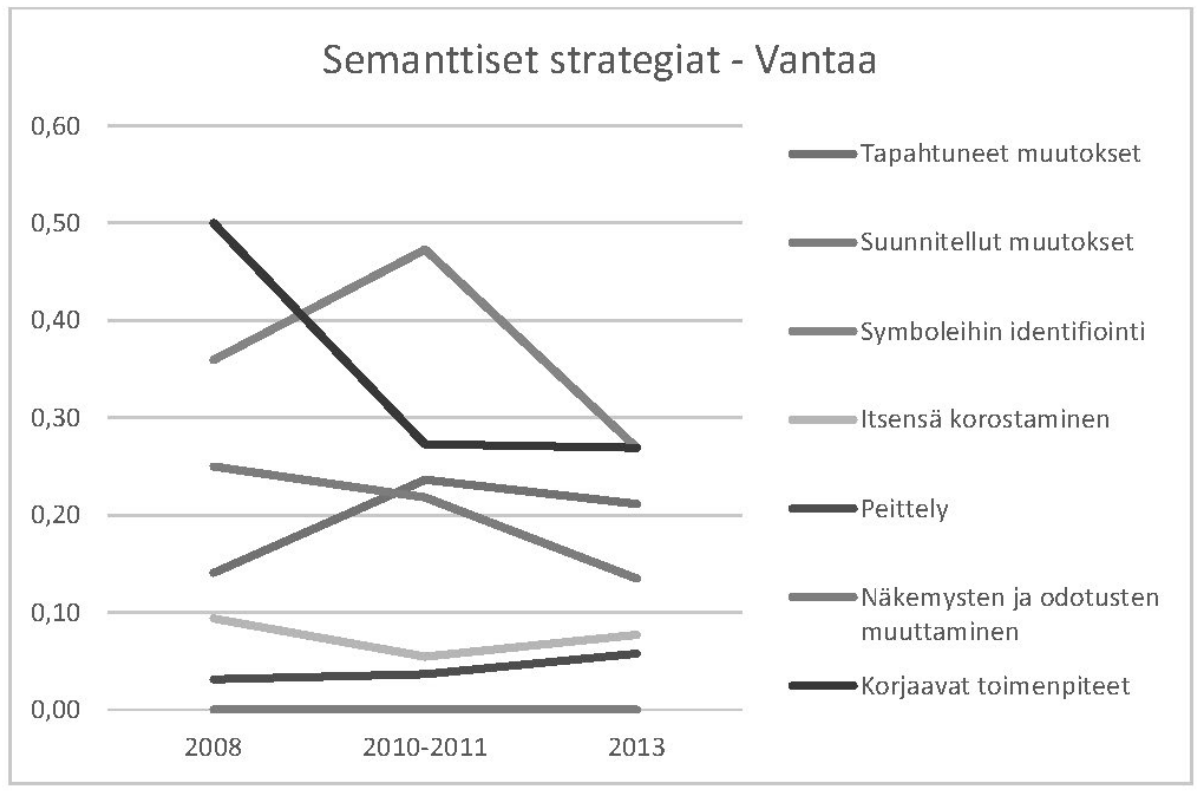

Kuvio 4. Semanttisten strategioiden käyttö - Vantaa

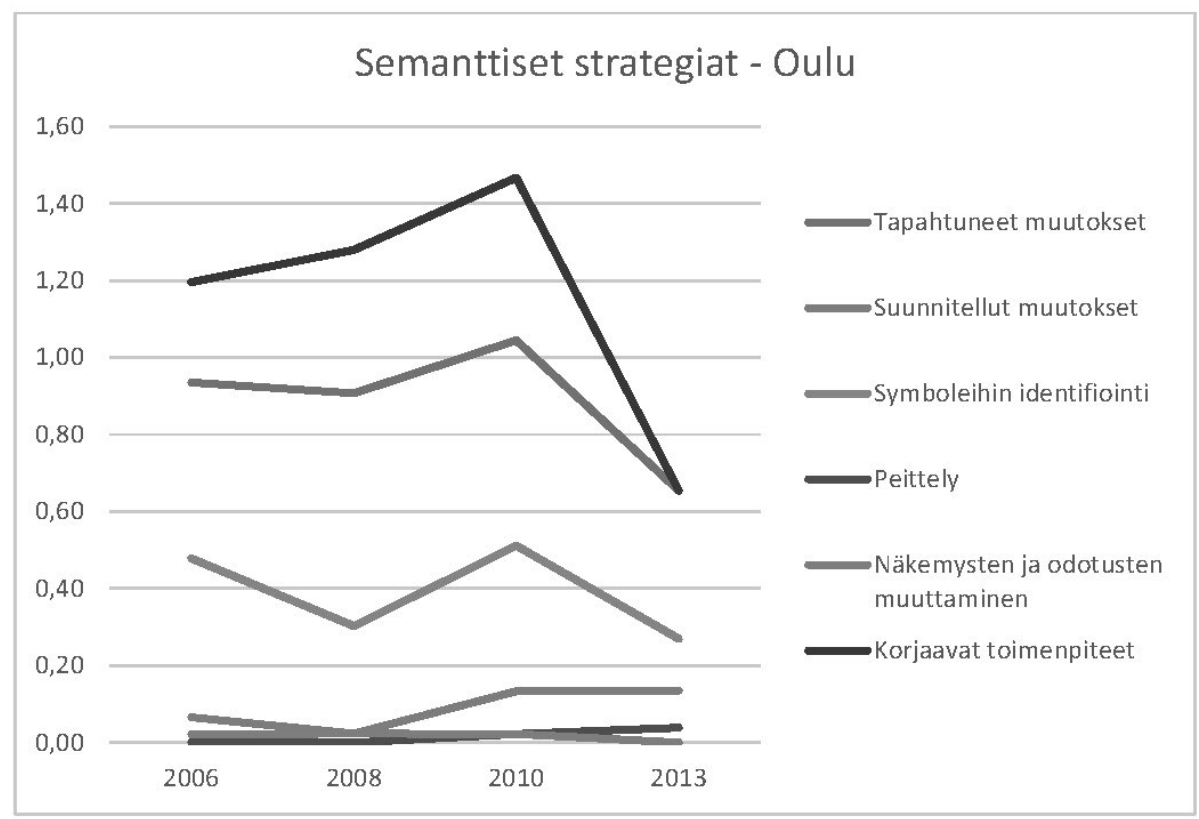

Kuvio 5. Semanttisten strategioiden käyttö - Oulu 
Muutoksesta kommunikointi on Helsingin raporteissa merkittävässä roolissa. Legitimointistrategioista käytetyimpiä ovat korjaavat toimenpiteet, tapahtuneet muutokset sekä suunnitellut muutokset (Kuvio 1). Jo toteutettua tai suunnitteilla olevaa toiminnan muuttamista on kuvattu raporteissa sekä konkreettisin esimerkein että epämääräisemmillä ilmaisuilla. Näkemysten ja odotusten muuttaminen sekä peittelystrategian käyttö ovat hyvin vähäisiä Helsingin raporteissa, samoin itsensä korostamista esiintyy raporteissa melko vähän. Symboleihin identifiointia on havaittavissa jonkun verran, mutta ei sitäkään merkittävästi.

Helsingin vuoden 2013 ympäristöraportissa on käytetty runsaasti nostoja eli tekstistä otettuja katkelmia. Tämä voidaan nähdä legitimointikeinona, sillä positiivisia asioita korostetaan nostojen avulla. Esimerkkinä positiivisesta korostamisesta on nosto: "Yli 300 auditoitua Ekokompassi- ja Ilmastokumppaniyritystä sekä Itämerihaasteen vastaanottanutta organisaatiota!'. Lausahduksen positiivista sävyä on korostettu päättämällä se huutomerkkiin. Nostojen käytössä on huomattavissa myös viitteitä peittelystrategiasta. Esimerkkinä tästä on nosto: "Kaupungin omistamien metsien luonnon monimuotoisuuden kannalta arvokkaiden kohteiden inventointi valmistui.". Raportin tekstissä samainen lause kuitenkin jatkuu "...lukuun ottamatta saaristoa." Tekstissä ei kerrota kuinka suuren osan saariston kohteet kattaisivat ja nostosta saakin todellisuudesta poikkeavan kuvan. Helsingin vuoden 2013 raportissa on uutena elementtinä myös Ympäristöpolitiikka 2020 ja 2050 -osiot, joissa esitellään ympäristöpoliittisia tavoitteita tulevaisuudelle. Tämä selittää osaltaan suunniteltuja muutoksia ja korjaavia toimenpiteitä kuvaavien strategioiden kasvua kyseisenä vuonna (Kuvio 1). Korjaavat toimenpiteet -strategiaa on nähtävissä monissa eri ilmaisuissa kuten: "Helsinki on eturivin toimija...", ”...öljyntorjunnan vaikuttavuus ...on merkittävä useimmissa olosuhteissa" sekä "öljyntorjunta-apu on huomattavan tehokasta" Tekstissä käytetään paljon epätarkkoja ilmaisuja kuten huomattava ja merkittävä, jotka eivät kuvaa toimintaa konkreettisesti.

Espoon raporteissa (Kuvio 2) esiintyy paljon ilmaisuja, jotka liittyvät toiminnan muuttamiseen. Mielikuvien muokkaamiseen, varsinkin symboleihin identifiointia esiintyy melko paljon. Muita strategioita on Espoon raporteissa käytetty vähäisesti tai ei ollenkaan. Etenkin peittelystrategian käyttö on hyvin vähäistä. Korjaavia toimenpiteitä kuvaavat ilmaukset lisääntyivät Espoossa vuonna 2008. Esimerkkinä tällaisista lausahduksista voidaan pitää lausetta: "Jotkut yksiköt ovat laatineet omia ympäristöohjelmia." "Jotkut yksiköt" on epätarkka ilmaisu eikä yksiköiden määrää tarkenneta tekstissä. Vuosien 2010 ja 2013 ympäristöraporteissa korjaavista toimenpiteistä kommunikoitiin enemmän. Tämä johtuu osaltaan siitä, että raportteihin on lisätty Espoon ympäristöpolitiikan toteutumista käsittelevä osio. Ympäristöpolitiikan toteutumista ja tulevia tavoitteita on arvioitu epätarkoin ilmaisuin ja konkreettisia esimerkkejä on käytetty vähemmän.

Tampereen raporteissa (Kuvio 3) esiintyi symboleihin identifiointia selvästi enemmän kuin muita strategioita vuosina 2006-2008. Vuosina 2010 ja 2013 eri strategioiden käytön välinen hajonta on huomattavasti pienempää. Vaikka monien strategioiden määrissä esiintyy myös ajoittaista kasvua edellisvuosiin verrattuna, on semanttisten strategioiden käyttö kokonaisuudessaan vähentynyt joka vuosi. Legitimointistrategioiden käytön huomattava väheneminen selittyy sillä, että vuonna 2010 Tampere muutti raportointikäytäntöään, kun siirryttiin perinteisemmästä raporttimuodosta ympäristönhallintaa käsitteleviin diaesityksiin, jotka ovat aikaisempia raportteja lyhyempiä ja sisältävät huomattavasti vähemmän tekstiä.

Symboleihin identifiointia ilmenee Tampereen ympäristöraporteissa selvästi enemmän kuin muita strategioita. Lisäksi on käytetty itsensä korostamista sekä korjaavista toimenpiteistä ja tapahtuneista muutoksista kommunikointia. Suunniteltuja muutoksia, näkemysten ja odotusten muuttamista sekä peittelyä ei ole käytetty juuri ollenkaan. Toiminnan muuttamiseen liittyvät strategiat ovat melko pienessä osassa legitimointistrategioiden käyttöä. Mielikuvien muokkaamista esiintyy selvästi enemmän.

Vantaan ympäristöraporteissa mielikuvien muokkaamiseen liittyvä korjaavat toimenpiteet -strategia oli vuonna 2008 korkealla tasolla, jonka jälkeen strategian käyttö väheni merkittävästi. Symboleihin identifiointi lisääntyi vuoden 2010-2011 raportissa, mutta väheni 
jälleen vuoden 2013 raportissa. Vaihtelua esiintyy myös tapahtuneisiin muutoksiin keskittyvissä ilmaisuissa, mutta vaihtelu ei ole kovinkaan suurta. Suunnitelluista muutoksista kommunikointi on laskenut tasaisesti tarkasteluajanjaksona. Näkemysten ja odotusten muuttamista ei Vantaan raporteissa ole havaittavissa yhtään. Peittelyä ja itsensä korostamistakin on käytetty vähän ja vuosittain esiintyvä vaihtelu on kyseisten strategioiden määrissä hyvin pientä. Eniten raporteissa esiintyy symboleihin identifiointia ja korjaavia toimenpiteitä, jotka molemmat liittyvät mielikuvien muokkaamiseen. Itsensä korostamista, peittelyä sekä näkemysten ja odotusten muuttamista esiintyy raporteissa hyvin vähän tai ei ollenkaan.

Oulun ympäristöraporteissa peittelystrategiaa, näkemysten ja odotusten muuttamista, itsensä korostamista ja suunnitelluista muutoksista kommunikointia on vähän. Vähäinen määrä liittyy myös symboleihin identifiointiin. Eniten Oulun ympäristöraporteissa on korjaavia toimenpiteitä kuvaavia ilmaisuja. Toiminnan muuttamiseen liittyvien strategioiden käyttö kattaa vähän yli kolmanneksen strategioiden käytöstä. Mielikuvien muokkaamista on havaittavissa siis selvästi enemmän Oulun raporteissa. Muita semanttisia strategioita ei ole käytetty juuri ollenkaan

\section{Yhteenveto semanttisten strategioiden käytöstä}

Taulukossa 3 esitetään yhteenvetona kaikkien semanttisten legitimointistrategioiden käyttö eri kaupungeissa. Taulukossa strategioiden määrät ovat suhteutettuna raporttien sivumääriin sekä strategioita kuvaavien ilmaisujen absoluuttisiin kokonaismääriin.

\section{Taulukko 3. Semanttisten strategioiden käytön jakaantuminen kaupungeittain}

$\begin{array}{ll}\text { Suhteelliset } & \text { Absoluuttiset } \\ \text { Helsinki } 41 \% & \text { Oulu } 33 \% \\ \text { Oulu } 25 \% & \text { Espoo } 23 \% \\ \text { Espoo } 17 \% & \text { Helsinki } 17 \% \\ \text { Tampere } 9 \% & \text { Vantaa } 14 \% \\ \text { Vantaa } 9 \% & \text { Tampere } 13 \%\end{array}$

Helsinki erottuu joukosta, sillä se on käyttänyt lähes kaikkia strategioita enemmän kuin muut kaupungit. Raporttien sivumääriin suhteutettuna Helsinki on käyttänyt selvästi eniten semanttisia legitimointistrategioita. Helsingin suhteellinen osuus kattaa 41 prosenttia kaikesta semanttisten strategioiden käytöstä. Myös ilmaisujen absoluuttisilla määrillä mitattuna Helsingin osuus on yllättävän korkea, vaikka Helsingin raportit ovat huomattavasti muiden kaupunkien raportteja lyhyempiä (Taulukko 3) Oulun prosenttiosuudet ovat korkealla sekä raporttien sivumääriin suhteutettuna että absoluuttisin määrin mitattuna. Tämä johtuu osaltaan jo aiemmin mainituista osioista raporteissa, joissa käsitellään ympäristöpoliittisten tavoitteiden toteutumista ja tehtyjä toimenpiteitä.

Absoluuttisesti mitattuna Espoon osuus semanttisten strategioiden käytöstä on melko suuri, 23 prosenttia. Espoon raportit ovat kuitenkin melko pitkiä ja kun strategioiden käyttö suhteutetaan raporttien sivumääriin. Tampere ja Vantaa ovat käyttäneet semanttisia legitimointistrategioita vähiten sekä suhteellisesti että absoluuttisesti mitattuna. Vantaan osalta tulokset kuitenkin vääristyvät, sillä Vantaan osalta aineisto koostuu kolmesta raportista, kun muilla kaupungeilla raportteja on neljä. On vaikea sanoa, kuinka korkealle Vantaan prosenttiosuudet kohoaisivat, jos raportteja olisi tarkastelussa saman verran kuin muilla kaupungeilla.

Taulukko 4. Semanttisten strategioiden käytön jakaantuminen

Korjaavat toimenpiteet $32 \%$

Tapahtuneet muutokset $24 \%$

Symboleihin assosiointi $22 \%$

Suunnitellut muutokset $12 \%$

Itsensä korostaminen $7 \%$

Peittely $2 \%$

Näkemysten ja odotusten muuttaminen $2 \%$

Taulukko 4 havainnollistaa kuinka paljon kutakin semanttista legitimointistrategiaa on käytetty tarkastelluissa ympäristöraporteissa yhteensä. 32 prosenttia kaikista ilmaisuista kuvaa korjaavia toimenpiteitä. Ympäristönhallinnan tavoitteisiin ja toimenpiteisiin liittyviä epätarkkoja ilmaisuja on selvästi eniten. Seuraavaksi eniten 
on kuitenkin kuvattu toteutettuja toimenpiteitä konkreettisesti ja tapahtuneisiin muutoksiin liittyvän strategian käyttö kattaakin 24 prosenttia kaikkien strategioiden käytöstä (Taulukko 3). Myös symboleihin identifiointia esiintyy melko paljon tarkasteltujen kuntien ympäristöraporteissa. 22 prosenttia kaikista ilmaisuista liittyy symboleihin identifiointiin. Tulevaisuuden tavoitteista ja kehityssuunnitelmista ei ole kerrottu paljoakaan konkreettisesti. Suunnitellut muutokset -strategia kattaa vain 12 prosenttia strategioiden käytöstä. Tarkastelluissa raporteissa on keskitytty kertomaan enemmän jo toteutetuista toimenpiteistä kuin suunnitteilla olevasta toiminnasta. Itsensä korostamista, peittelyä sekä näkemysten ja odotusten muuttamista on havaittavissa tarkastelluissa raporteissa vain vähän. Itsensä korostaminen kattaa 7 prosenttia semanttisten strategioiden käytöstä ja kahta viimeksi mainittua strategiaa on käytetty vain 2 prosentin verran kumpaakin. Semanttisiin strategioihin kuuluvista ilmaisuista 36 prosenttia lukeutuu toiminnan muuttamiseen ja 64 prosenttia mielikuvien muokkaamiseen. Näin ollen kuntien voidaan tulkita käyttävän legitimointistrategioita ainakin osittain antaakseen positiivisen vaikutelman kunnan ympäristönhallinnasta.

\section{Visuaaliset strategiat}

Kuviossa 6 esitetään visuaalisten strategioiden käyttöä Helsingin ympäristöraporteissa. Neutraalien graafien ja toimintaan liittyvien valokuvien käyttö on pysynyt melko tasaisena, kun muiden strategioiden käyttö on ollut vaihtelevampaa. Eniten Helsingin ympäristöraporteissa on käytetty positiivista kehitystä kuvaavia graafeja sekä valokuvia, jotka eivät suoraan kuvaa organisaation toimintaa. Tämä viittaa mahdollisesti symboliseen lähestymistapaan, jolloin organisaatio pyrkii luomaan mielikuvan vastuullisesta toiminnasta (Hrasky 2012; Cho, Michelon \& Patten 2012). Määrällisesti Helsingin raporteissa on käytetty melko saman verran graafista esitystapaa ja valokuvia. Valokuvia raporteissa on yhteensä 42 ja graafeja vastaavasti 36 . Valokuvista selvästi enemmän on käytetty kuvia, joilla ei ole suoraa yhteyttä toimintaan tai raportoituihin asioihin. Koska visuaalisista strategioista eniten on käytetty toimintaan suoraan liittymättömiä valokuvia ja positiivista trendiä kuvaavia graafeja, on mahdollista, että visuaalisia keinoja on käytetty legitimointitarkoituksessa luomaan positiivinen kuva kunnasta. Visuaalisten strategioiden käyttö kokonaisuudessaan on kuitenkin vähentynyt tarkastelluissa Helsingin ympäristöraporteissa.

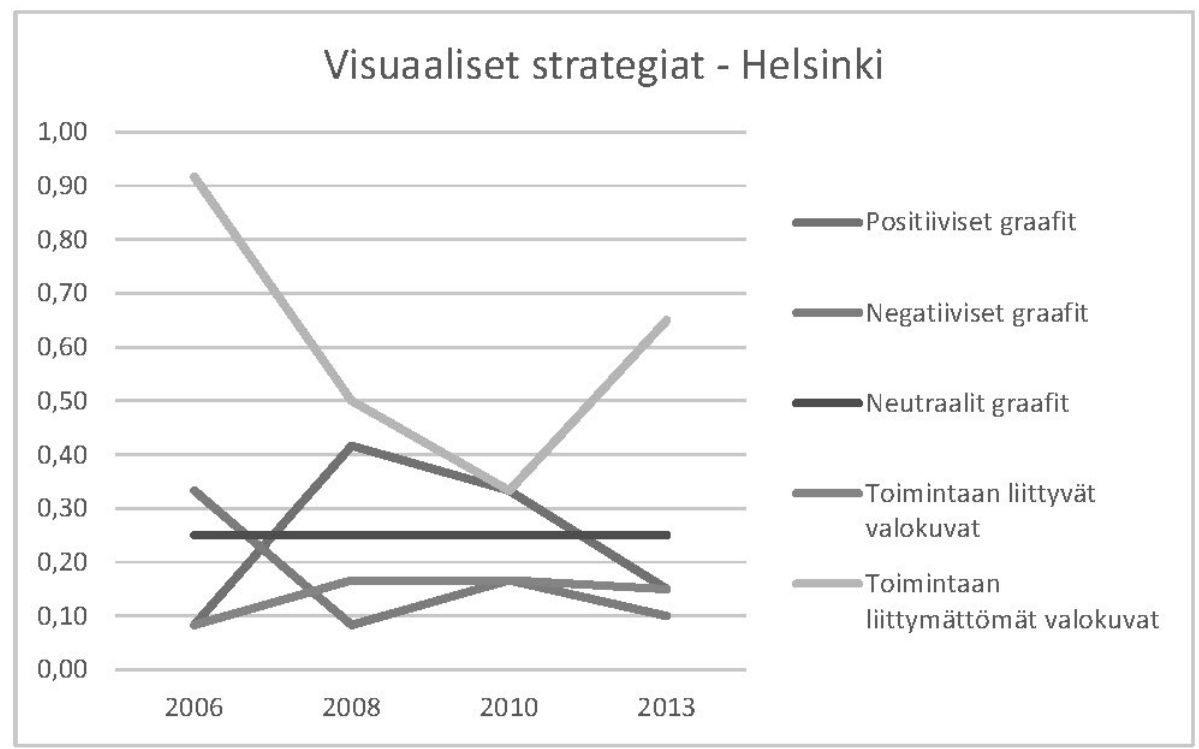

Kuvio 6. Visuaalisten strategioiden käyttö - Helsinki 


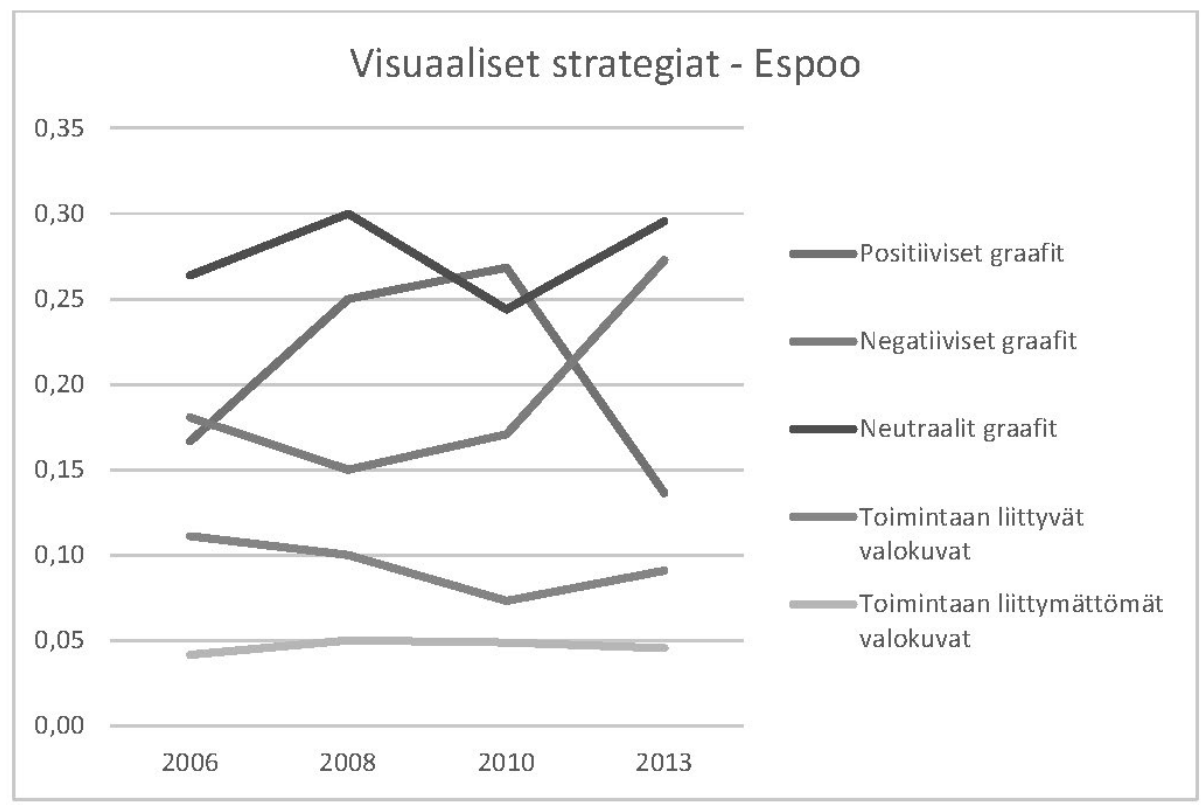

Kuvio 7. Visuaalisten strategioiden käyttö - Espoo

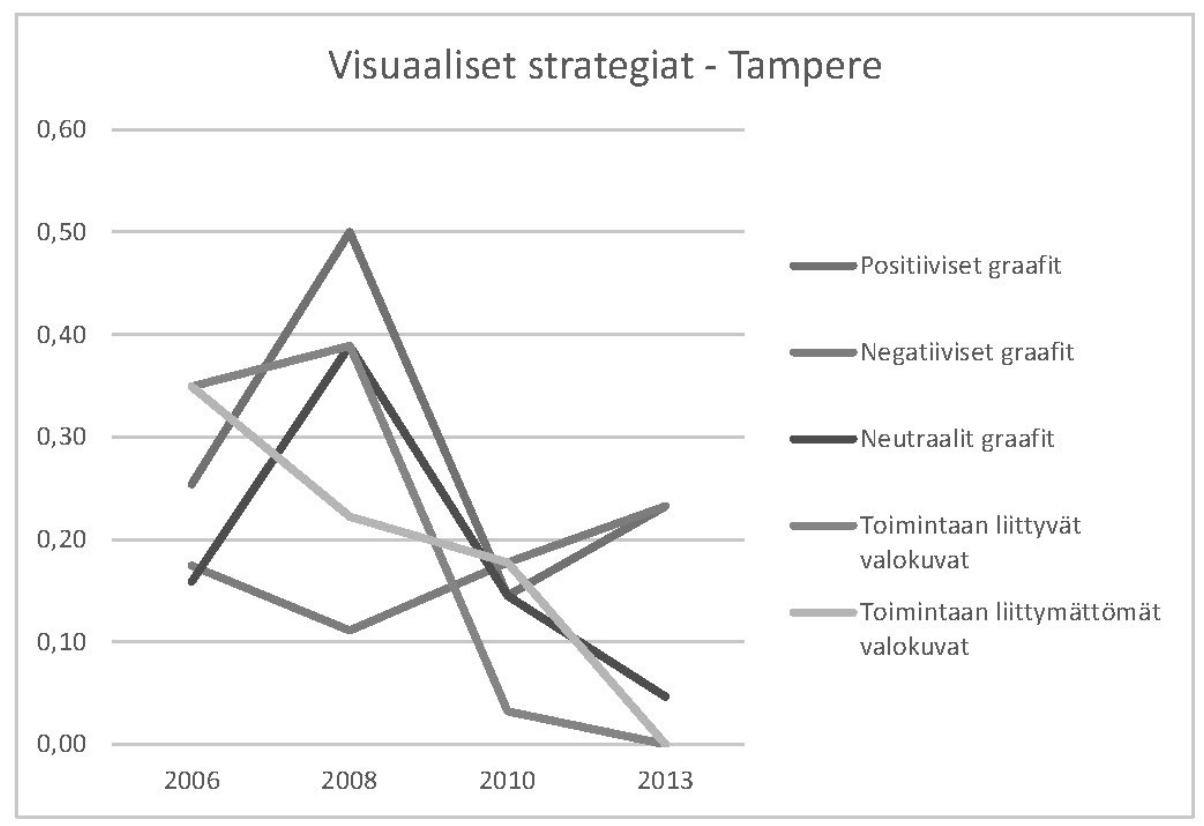

Kuvio 8. Visuaalisten strategioiden käyttö - Tampere 


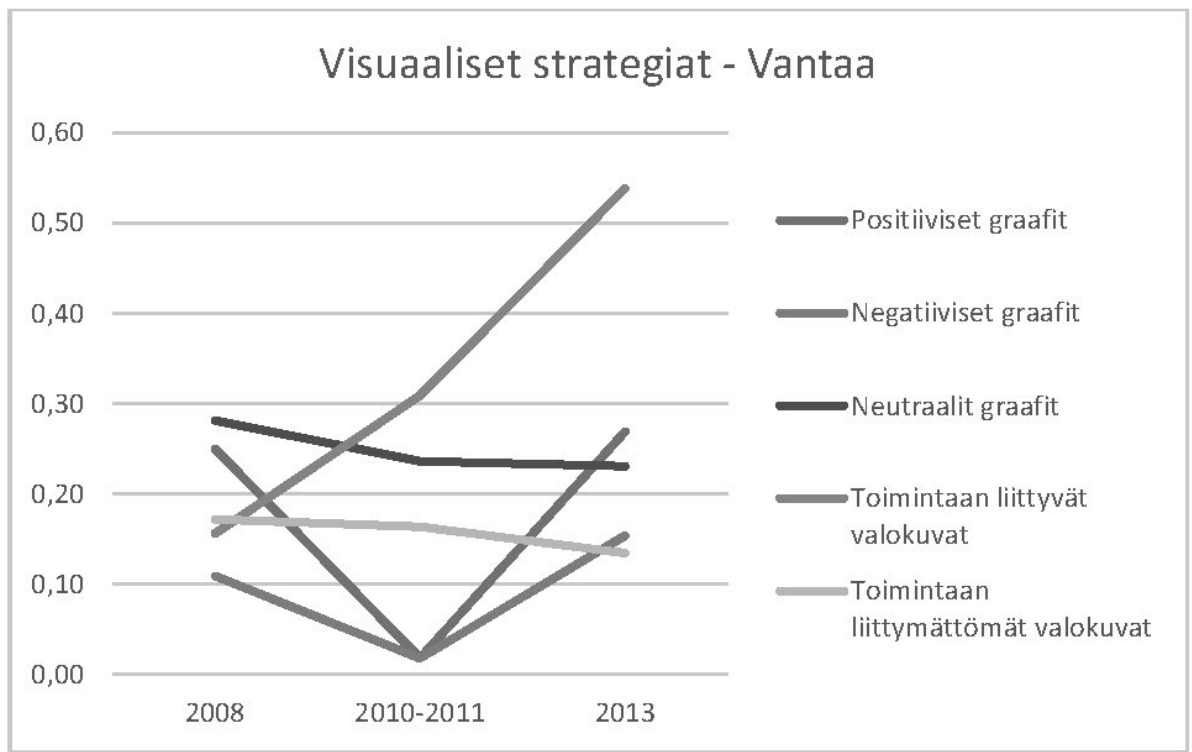

Kuvio 9. Visuaalisten strategioiden käyttö - Vantaa

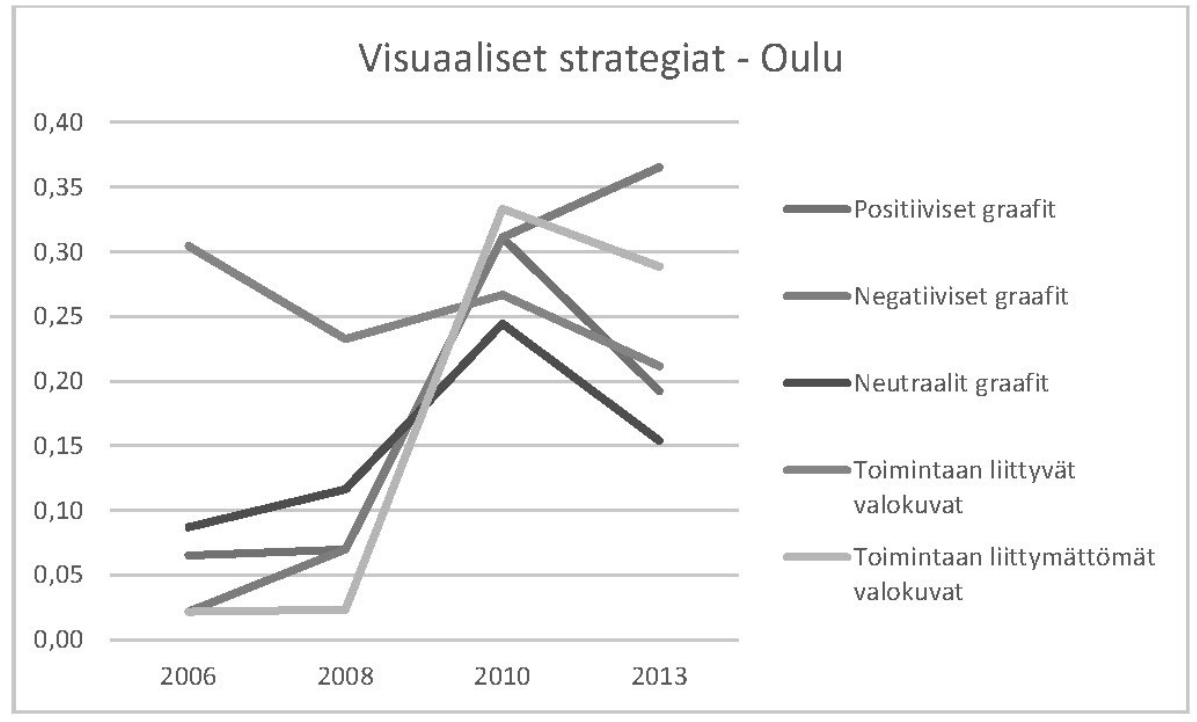

Kuvio 10. Visuaalisten strategioiden käyttö - Oulu 
Visuaalisten strategioiden käyttöä Espoon ympäristöraporteissa havainnollistetaan kuviossa 7. Valokuvien käyttö on pysynyt melko tasaisena vuodesta toiseen. Sen sijaan graafien käytössä esiintyy enemmän vaihtelua. Sekä positiivisten, negatiivisten että neutraalien graafien määrä raporteissa vaihtelee vuosittain. Vuosittaisen määrällisen vaihtelun ja erilaisten graafien tasaisen jakautumisen vuoksi graafien osalta ei voida havaita legitimointiin viittaavaa positiivisten asioiden korostamista. Tutkimuksessa ei arvioida graafien vääristyneisyyttä tai harhaanjohtavien skaalojen käyttöä, mutta huomioitakoon, että Espoon ympäristöraporteissa graafit näyttävät päällisin puolin luotettavilta eikä ilmeistä graafien vääristelyä ole nähtävissä. Valokuvien käyttö on Espoon ympäristöraporteissa hyvin vähäistä. Graafien verrattain suuri määrä viittaa moraalisen legitimaation tavoitteluun, jolloin visuaalisia strategioita käytetään kuvaamaan todellisia saavutuksia (Hrasky 2012). Valokuvien maltillisen käytön lisäksi toimintaa kuvaavien valokuvien suurempi määrä tukee käsitystä aidosti vastuullisen toiminnan korostamisesta (Hrasky 2012). Visuaalisten strategioiden käyttö on Espoon ympäristöraporttien osalta kasvanut selvästi tarkasteluajanjaksona.

Kuviossa 8 esitetään visuaalisten strategioiden käytön kehitystä Tampereen ympäristöraporteissa. Neutraalien ja positiivisten graafien käyttö lisääntyi huomattavasti vuonna 2008, mutta laski rajusti vuoden 2010 raportissa. On kuitenkin todettava, että määrälliset erot eivät kyseisten graafien kohdalla ole kovinkaan suuret, mutta suhteutettuna raporttien sivumääriin erot ovat merkittäviä. Suurin osa graafeista kuvaa positiivista kehitystä. Positiivista kehitystä kuvaavien graafien suhteellisen suuri määrä saattaa olla merkki symbolisesta lähestymistavasta, jossa pyritään korostamaan positiivisia asioita (Cho ym. 2012). Graafinen esitystapa kattaa visuaalisten strategioiden käytöstä selvästi suuremman osan, myös valokuvia on käytetty runsaasti. Tämä viittaa moraalisen legitimaation tavoitteluun, jolloin kvantitatiivisella tiedolla kuvataan aidosti vastuullista toimintaa (Hrasky 2012).

Toimintaan liittymättömien valokuvien määrä on laskenut melko tasaisesti tarkasteluajanjaksona. Toimintaan liittyvien valokuvien mää- rä taas kasvoi hieman vuonna 2008, jonka jälkeen määrä romahti. Vuonna 2013 valokuvia ei käytetty enää ollenkaan Tampereen raportissa. Vuosina 2010 ja 2013 valokuvia on käytetty Tampereen muussa ympäristöasioita koskevassa raportoinnissa, mutta tässä tutkimuksessa on haluttu tutkia kyseisten vuosien osalta kestävään kehitykseen keskittyviä esityksiä, koska ne vastaavat sisällöltään aikaisempien vuosien kestävän kehityksen raportteja.

Visuaalisten legitimointistrategioiden käyttö on tarkastelluissa Tampereen raporteissa vähentynyt yhteensä selvästi. Ainakin osittain huomattava vähentyminen selittyy jälleen kerran siirtymisellä perinteisemmästä raportointitavasta tiiviimpään diaesitysmuotoon.

Kuviossa 9 esitetään visuaalisten legitimointistrategioiden käyttöä Vantaan raporttien osalta. Graafista esitystä ja valokuvia on käytetty lähes yhtä paljon; graafit kattavat yli puolet ja valokuvat lähes puolet strategioiden käytöstä. Sekä positiivisten että negatiivisten graafien käyttö väheni reilusti vuoden 2010-2011 raportissa, ja vuonna 2013 molempien graafien käyttö lisääntyi jälleen. Graafien käytössä ei ole huomattavissa pragmaattisen legitimoinnin tavoitteluun liittyvää positiivista korostamista. Toimintaan liittyvien kuvien suurempi määrä voidaan tulkita merkiksi moraalisen legitimaation tavoittelemisesta, jolloin valokuvilla korostetaan todellisia saavutuksia (Hrasky 2012). Toimintaa kuvaavien valokuvien määrä on kuvion 9 mukaan ollut jatkuvassa kasvussa vuodesta 2008 lähtien. Toimintaan liittymättömien valokuvien määrä on pysynyt melko tasaisena.

Oulun graafit on esitetty kuviossa 10 . Toimintaan liittyvien valokuvien käytön kehitys on ollut melko tasaista verrattuna muihin visuaalisiin strategioihin. Erilaisia graafeja sekä toimintaan liittymättömiä valokuvia esiintyy vuosien 2010 ja 2013 raporteissa selvästi enemmän kuin vuosina 2006 ja 2008. Graafien käytössä ei siis ole havaittavissa legitimointiin viittaavaa positiivisten asioiden korostamista. Graafien ja valokuvien tasainen suhde viittaa siihen, ettei valokuvia käytettäisi mielikuvien muokkaamiseen ja positiivisen korostamiseen (Hrasky 2012).

Kuvat, jotka eivät suoraan liity raportoituihin asioihin kattavat 40 prosenttia kuvien käytöstä. Toimintaan liittymättömiä valokuvia ei käytetty 
vuosina 2006-2008 juuri ollenkaan, mutta vuosina 2010 ja 2013 on niiden käyttö mennyt toimintaan liittyvien kuvien edelle. Toimintaan liittyvien kuvien määrä on kuitenkin pysynyt melko samana vuodesta toiseen eli valokuvien käyttöä yleisesti on lisätty reilusti vuodesta 2010 eteenpäin. Toimintaan liittymättömien valokuvien suuri määrä vuosina 2010 ja 2013 on ristiriidassa aiemman tulkinnan kanssa, jonka mukaan valokuvia käytettäisiin vain graafien tukena. Toimintaan liittymättömien valokuvien huomattava lisäys on mahdollisesti tehty legitimointitarkoituksessa ja niillä saatetaan pyrkiä mielikuvien muokkaamiseen. Visuaalisten strategioiden käytössä on Oulun kohdalla tapahtunut huomattavaa kasvua.

\section{Yhteenveto visuaalisten strategioiden käytöstä}

Taulukossa 5 esitetään visuaalisten strategioiden käytön laajuus kaupungeittain sekä suhteellisesti että absoluuttisesti mitattuna.

Taulukko 5. Visuaalisten strategioiden käytön jakaantuminen kaupungeittain

$\begin{array}{ll}\text { Suhteelliset } & \text { Absoluuttiset } \\ \text { Helsinki } 29 \% & \text { Tampere } 26 \% \\ \text { Tampere } 21 \% & \text { Oulu 22\% } \\ \text { Oulu } 19 \% & \text { Vantaa } 22 \% \\ \text { Espoo } 17 \% & \text { Espoo } 20 \% \\ \text { Vantaa } 15 \% & \text { Helsinki } 10 \%\end{array}$

Suhteutettuna raporttien sivumääriin Vantaa on käyttänyt vähiten visuaalisia legitimointistrategioita. Absoluuttisesti mitattuna Vantaan käyttämät visuaaliset strategiat kattavat 22 prosenttia kaikesta strategioiden käytöstä (Taulukko 5). Tämä on melko suuri prosenttiosuus ottaen huomioon, että Vantaan osalta aineistoon kuuluu vain kolme raporttia. Raporttien pienemmästä määrästä huolimatta Vantaa on käyttänyt absoluuttisesti kaikkein eniten toimintaa aidosti heijastavia valokuvia.
Taulukko 6. Visuaalisten strategioiden käyttö

Toimintaan liittymättömät valokuvat $23 \%$

Positiiviset graafit $21 \%$

Neutraalit graafit $21 \%$

Toimintaan liittyvät valokuvat $19 \%$

Negatiiviset graafit $16 \%$

Taulukko 6 havainnollistaa visuaalisten strategioiden käyttöä yhteensä. Eniten tutkittavissa ympäristöraporteissa on käytetty toimintaan liittymättömiä valokuvia ja positiivisia graafeja. Vähiten on käytetty negatiivista kehitystä kuvaavia graafeja. Tämä viittaa mahdollisesti positiivisen mielikuvan luomiseen (Hrasky 2012; Cho ym. 2012). On kuitenkin huomioitava, että strategioiden käytön laajuutta kuvaavissa prosenttiosuuksissa ei ole kovinkaan suuria eroja eikä pragmaattisen legitimoinnin tavoitteluun liittyviä strategioita ole käytetty merkittävästi enempää kuin muita strategioita. Kaiken kaikkiaan visuaalisia strategioita on käytetty melko tasaisesti tutkittavissa raporteissa.

\section{JOHTOPÄÄTELMÄT}

Tutkimuksen tarkoituksena oli kartoittaa minkälaisia legitimointistrategioita Suomen suurimmat kunnat käyttävät ympäristöraportoinnissaan. Teoreettinen viitekehys laadittiin aiemman teorian pohjalta, ja se sisälsi semanttiset ja visuaaliset strategiat ja näiden alakategoriat. Aineisto koottiin Suomen suurimpien kuntien julkaisemista ympäristöraporteista. Menetelmänä käytettiin teorialähtöistä sisällönanalyysia. Tulokset koottiin taulukoihin, jotka esitettiin graafisessa ja taulukkomuodossa.

Tutkimuksessa kävi ilmi, että semanttisten strategioiden käytössä eniten on käytetty korjaavia toimenpiteitä kuvaavia ilmaisuja. Paljon on kuitenkin myös kerrottu konkreettisesti toteutetuista toimenpiteistä, mutta konkreettisia tulevaisuuden suunnitelmia ei ole kuvattu kovinkaan laajasti. Konkreettiset esimerkit keskittyvät siis menneeseen tulevien kehitysideoiden sijaan. Raporteissa esiintyy myös jonkin verran symboleihin identifiointia. Itsensä korostamista, peittelyä sekä näkemysten ja odotusten muuttamista on havaittavissa vain vähän. Etenkin peittelyn puuttuminen voidaan nähdä positiivisena 
asiana. Epäedullisista ja kehitystä kaipaavista asioista on kerrottu avoimesti raporteissa. Myös negatiivisia asioita on tuotu esille.

Huomio kiinnittyi myös erilaisten case-esimerkkien ja haastatteluiden käyttöön osana raportointia. Caset ja haastattelut voivat itsessään olla osa legitimointia ja niillä saatetaan pyrkiä vahvistamaan positiivista kuvaa organisaatiosta. Lähes kaikki tarkastellut kunnat käyttivät caseja tai haastatteluja raporteissaan. Tulkintaa haastattelujen käyttämisestä osana legitimointia vahvistaa esimerkiksi Espoon vuoden 2008 raportissa oleva ministeri Lehtomäen haastattelu. Haastattelu voidaan nähdä osittain symboleihin identifiointina, sillä ympäristöministerin ajatellaan yleisesti olevan legitiimi toimija. Haastattelujen avulla pystytään vetoamaan lukijaan tehokkaasti, sillä kirjoituksen sävy on usein vapaamuotoisempi verrattuna muuhun raporttiin. Kun ympäristöasiat liitetään johonkin yksittäiseen tahoon tai ihmiseen, niin asiasta tulee konkreettisempi ja lukija saa kuvan siitä, että ympäristöasioiden eteen tehdään todellisia toimenpiteitä.

Vantaan kohdalla aineisto koostuu vain kolmesta raportista, kun muilla kaupungeilla tuloksiin on laskettu neljässä raportissa käytetyt legitimointistrategiat. Myös vaihtelua legitimointistrategioiden käytössä on vaikea arvioida luotettavasti vain kolmen vuoden perusteella. Tampereen osalta tulokset saattavat olla vääristyneitä, sillä raportoinnin siirtyminen diaesitysten muotoon kyseenalaistaa vertailukelpoisuuden muiden raporttien kanssa. Legitimointistrategioiden määrät on suhteutettu raporttien sivumääriin ja dioihin mahtuu selvästi vähemmän tekstiä kuin tekstitiedoston sivuihin. Näin ollen, tulokset saattavat vääristyä myös Tampereen osalta.

Julkisen sektorin legitimointistrategioiden käytön tutkiminen ympäristöraporteissa on tärkeää, koska kunnat muodostavat eräänlaisen esimerkin myös muille organisaatioille, joilta on vaikeaa edellyttää parempaa ympäristöasioiden raportointia kuin ne itse tekevät. Ympäristökysymysten tärkeyttä ei voida liikaa korostaa, ja luotettavien raporttien tuottaminen tulisikin olla ehdoton vaatimus. Eettiseltä kannalta tämän tulisi olla kuntien velvollisuus, kun taas kansalaisilla on oikeus saada oikeaa tietoa siitä, miten kunnat käyttävät verovaroja ympäristöasioihin. Julkisten palvelujen kehittämisen kannalta ympäristöraportteihin tulisi panostaa enemmän.

Kaiken kaikkiaan kuntien ympäristöraportoinnin taso ja rakenne osoittautuivat melko vaihteleviksi. Yhdenmukainen raportointi ja yhteiset indikaattorit puuttuvat, ja kuntien ympäristöasioiden raportoinnin vertailu tutkimuksessa on vaikeaa. Tässä artikkelissa käytetty viitekehys tarjoaa mahdollisuuden tarkastella kuntien raportteja yhdenmukaisesta legitimaatiostrategioiden näkökulmasta. Tutkimuksen luotettavuutta heikentää se, että vaikka strategiat onkin valmiiksi määritelty, on tutkijan subjektiivisen tulkinnan varassa mitkä ilmaisut tai sanamuodot kuuluvat minkäkin strategian piiriin. Joidenkin ilmaisujen kohdalla ei aina ole selvää lasketaanko se osaksi strategioiden käyttöä. Subjektiivisuus on kuitenkin kvalitatiiviseen tutkimukseen liittyvä piirre.

Aihepiiri tarjoaa runsaasti mahdollisuuksia aihetta käsitteleviin jatkotutkimuksiin. Kuntien legitimointikäytäntöjä voisi verrata yritysten käytäntöihin. Legitimointiin liittyen voitaisiin myös tutkia tarkemmin erilaisten haastattelujen ja casejen merkitystä raportoinnissa. Myös valokuviin ja graafeihin voisi perehtyä tarkemmin. Tässä tutkimuksessa ei esimerkiksi otettu huomioon graafien vääristelyä tai valokuvien kokoa ja sijoittelua. Näistäkin voisi löytyä legitimointimahdollisuuksia, joihin voisi syventyä tulevissa tutkimuksissa. 


\section{LÄHTEET}

Adams, Carol (2004). The ethical, social and environmental reporting-performance portrayal gap. Accounting, Auditing \& Accountability Journal, 17(5), 731-727.

Adams, Carol A., Hill, Wan-Ying, Roberts, Clare B. (1998). Corporate social reporting practices in Western Europe: legitimating corporate behaviour. The British Accounting Review, 30(1), 1-21.

Anttiroiko, Ari-Veikko (2004). Yhteiskuntavastuu ja sen määrittelyprosessi. Teoksessa Järvinen, Raija. (toim.), Yhteiskuntavastuu: näkökulmia yritysten ja julkisyhteisöjen yhteiskunnalliseen vastuuseen (s. 17-60).Tampere: Tampere University Press.

Amran, Azlan \& Ooi, S. K. (2014). Sustainability reporting: meeting stakeholder demands. Strategic Direction, 30(7), 38-41.

Azzone, G., Brophy, M., Noci, Giuliano, Welford, R. \& Young, William (1997). A Stakeholders' View of Environmental Reporting. Long range planning, 30(5), 699-709.

Bennett, Marin, James, Peter, \& Klinkers, Leon (1999). Sustainable measures : evaluation and reporting of environmental and social performance. Sheffield U.K.: Greenleaf Pub.

Benoit, William (1997). Image repair discourse and crisis communication. Public relations review 23(2), 177-186.

Boyd, Josh (2000). Actional Legitimation: No Crisis Necessary. Journal of Public Relations Research, 12(4), 341-353.

Bremser, W. G. (2014). A Growing Interest in Sustainability. CPA Journal, 84(3), 15-17.

Cho, Charles. H. (2009). Legitimation Strategies Used in Response to Environmental Disaster: A French Case Study of Total SA's Erika and AZF Incidents, 18(1), 33-62.

Cho, Charles. H., Michelon, Giovanna \& Patten, Dennis, M. (2012). Impression Management in Sustainability Reports: An Empirical Investigation of the Use of Graphs. Accounting \& the Public Interest, 12(1), 16-37.

Dowling, John \& Pfeffer, Jeffrey (1975). Organizational legitimacy: Social values and organizational behavior. Sociological Perspectives, 18(1), 122-136

Freedman, Martin \& Jaggi, Biggi (2010). Sustainability, environmental performance and disclosures. Advances in environmental accounting \& management, 4.

Gray, Rob, Owen David \& Adams, Carol (1996). Accounting \& accountability: changes and challenges in corporate social and environmental reporting. Prentice Hall.
Guenther, Edeltraud, Hoppe, Holger \& Poser, Claudia (2007). Environmental Corporate Social Responsibility of Firms in the Mining and Oil and Gas Industries: Current Status Quo of Reporting Following GRI Guidelines. Greener Management International, (53), 7-25.

Guthrie, James \& Parker, Lee. D. (1989). Corporate Social Reporting: A Rebuttal of Legitimacy Theory. Accounting \& Business Research , 19(76), 343-352.

Hahn, Rüdiger \& Lülfs, Regina (2014). Legitimizing Negative Aspects in GRI-Oriented Sustainability Reporting: A Qualitative Analysis of Corporate Disclosure Strategies. Journal of Business Ethics, 123(3), 401-420.

Hrasky, Sue (2012). Visual disclosure strategies adopted by more and less sustainability-driven companies. Accounting Forum, 36 (3), 154-165.

Jussila, Markku (2010). Yhteiskuntavastuu. Nyt. Infor: Vantaa.

Kalpala, Asmo (2004). Johdantopuheenvuoro. Teoksessa Järvinen, Raija (toim.) Yhteiskuntavastuu: näkökulmia yritysten ja julkisyhteisöjen yhteiskunnalliseen vastuuseen. Tampere University Press:Tampere.

Kim, Jeong-Nam, Bach, Seung B. \& Clelland Iain J. (2007). Stmbolic or Behavioral Corporate Reputatuin in High-Emission Industries. Corporate Reputation Review, 10(2), 77-98.

Knuutila, H. 2007. Ohje kunnan ympäristötilinpäätöksen laatimiseen - Tehty KUTU-ptojektissa. Efeko Oy. [Helsinki]: Canon Kuntatalo. Viitattu 11.11.2015.

Kolk, Ans (1999). Evaluating corporate environmental reporting. Business Strategy and the Environment, 8(4), 225-237.

Kuutoskaupunkien ekologisen kestävyyden indikaattorit 2006-2010. 2012. Haettu sivulta http://www.ouka.fi/documents/64417/5a261bfe-03d8-4efa-9c89-ad059a26c684, 11.1.2015.

Kuutoskaupunkien kestävän kehityksen indikaattorit 2004-2006. 2008. Haettu sivulta http:// www.ouka.fi/documents/64417/8f169b47f3b2-40a0-9fd9-363e9fa52d11, 11.1.2015.

Laki kuntien ympäristönsuojelun hallinnosta, 24.7.1986/64.

Laki kuntien ympäristönsuojelun hallinnosta, 1§ muutossäädös, 5.12.1996/1013.

Merkl-Davies, Doris. M. \& Brennan, Niamh (2007). Discretionary disclosure strategies in literature, 27, 116-194.

Michelon, Giovanna (2011). Sustainability Disclosure and Reputation: A Comparative 
Study. Corporate Reputation Review, 14(2), 79-96.

Mätäsaho, Risto \& Niskala, Mikael (1996). Ympäristölaskentatoimi. WSOY: Porvoo.

Mätäsaho, Risto \& Niskala, Mikael (1997). Ympäristölaskentatoimi ja valtaympäristö. Liiketaloudellinen aikakauskirja, 1, 76-91.

Niskala, Mikael \& Pretes, Michael (1995). Environmental reporting in Finland: A note on the use of annual reports. Accounting, Organizations and Society, 20(6), 457-466.

Nybom, Tanja (2016) Legitimointistrategiat Suomen suurimpien kuntien ympäristöraportoinnis$s a$. Pro gradu -työ, Jyväskylän yliopiston kauppakorkeakoulu.

O'Donovan, Gary (2002). Environmental disclosures in the annual report: extending the applicability and predictive power of legitimacy theory. Accounting, Auditing \& Accountability Journal, 15(3), 344-371.
O'Dwyer, Brendan, Owen, David \& Unerman, Jeffrey (2011). Seeking legitimacy for new assurance forms: The case of assurance on sustainability reporting. Accounting, Organizations and Society, 36(1), 31-52.

Schreier, Margrit (2012). Qualitative content anal$y$ sis in practice. Thousand Oaks (Calif.): Sage Publications. Lisäpainokset: Repr. 2013.

Tuomi, Jouni \& Sarajärvi, Anneli (2009). Laadullinen tutkimus ja sisällönanalyysi. Helsinki: Tammi.

Väestörekisterikeskus. (2014). Kuntien asukasluvut suuruusjärjestyksessä. Väestötietojärjestelmä. Haettu sivulta http://vrk.fi/default.aspx?docid $=8699$ \&site $=3 \&$ id $=0$ 11.1.2015.

Ympäristönsuojelulaki 86/2000, 25§. 